\title{
International funding cost and heterogeneous mortgage interest-rate pass-through:
}

\section{A bank-level analysis}

\author{
Quynh Chau Pham Holland a,b,*, Benjamin Liu ${ }^{\text {a }}$, Eduardo Roca ${ }^{\mathrm{a}}$ \\ ${ }^{a}$ Department of Accounting, Finance and Economics, Griffith Business School, Griffith University, \\ 170 Kessels Road, Nathan QLD 4111, Australia \\ ${ }^{b}$ Faculty of Banking and Finance, University of Finance and Marketing, \\ 2/4 Tran Xuan Soan Road, Tan Kieng, District 7, Ho Chi Minh City, Vietnam
}

Funding: This study was funded by the Vietnamese Government, Project 165_5877QĐ/BTCTW.

Conflict of Interest: We all declare that there is no conflict of interest.

\footnotetext{
* Corresponding author. Department of Accounting, Finance and Economics, Griffith Business School, Griffith University, 170 Kessels Road, Nathan QLD 4111, Australia. Tel.: +61 420750409

E-mail addresses: quynh.pham@griffithuni.edu.au (Q. C.P. Holland), b.liu@griffith.edu.au (B. Liu), e.roca@griffith.edu.au (E. Roca). ORCID numbers: 0000-0002-1976-1729 (Q.C.P. Holland), 0000-0002-1542-8208 (E. Roca).
} 
International funding cost and heterogeneous mortgage interest-rate pass-through: A bank-level analysis

\begin{abstract}
This study examines the transmission of the cost-of-funds rates, domestically and internationally, to owner-occupied housing interest rates at the bank level for the period 2002(7)-2015(12) in Australia. Three main issues, cross-sectional dependence, parameter heterogeneity, and asymmetry, have been considered using the linear and nonlinear commonfactor Augmented Mean Group estimators. Significant unobservable coefficients in all estimates ascertain that unobserved common factors arising from both national and global shocks have a significant influence on mortgage rate transmission. The results of sizable heterogeneity and asymmetry, found in all estimates while controlling for cross-sectional correlations, highlight the substantial effect of the foreign-funds rate on long-run mortgage price-setting. We find a closer connection between mortgage interest rates and international funding cost; we have also confirmed a declining transmission of the policy rate after the 2008 global financial crisis.
\end{abstract}

Keywords Asymmetry, heterogeneity, cross-sectional dependence, interest rate pass-through, bank mortgages, AMG models

JEL Classifications G21, E43, E52, E58 


\section{Introduction}

The 2008 global financial crisis (GFC) had severe impact on banking stability with a large degree of country heterogeneity. The study of heterogeneity and asymmetry in interest rate pass-through (IRPT), therefore, has been renewed, with its main focus now on developed mortgage markets. Most recent papers, such as Bernhofer and Van Treeck (2013), Lim, Tsiaplias, and Chua (2013), and Sathye (2013), investigate heterogeneity in IRPT for advanced mortgage markets at cross-country or country levels. This set of the literature confirms the occurrence of short-term heterogeneity and long-term homogeneity in the passthrough. In relation to asymmetry, a few studies, which use bank-level data for Belgium (De Graeve et al. 2007), Netherlands (De Haan \& Sterken 2011), the UK (Fuertes et al. 2010), or Czech Republic (Horváth \& Podpiera 2012), find extensive existence of short-term asymmetry in the IRPT. Apergis and Cooray (2015) document that the four major banks in Australia still yield asymmetry in pass-through from policy rates to their retail rates after the GFC, while this asymmetry does not exist for the UK and US.

Two imperative issues have been neglected in the IRPT literature. Disregarding crosssection dependence (CD) is the first major shortcoming. Cross-section correlation, which is typically encountered in the data of economic growth and credit spreads, is theoretically inherent in interest rate panels (Omay, Çorakc1, \& Emirmahmutoglu 2017). Depository institutions nationally and globally operate in an interactive environment through economic, regulatory, political and other channels. Their price-setting policies are significantly subject to common phenomena ranging from national policy changes to global economic shocks such as the recent financial and sovereign debt crises. The contemporary literature on growth and econometrics has established solid foundations in the presence of CD properties in the macro panel data which arise from common factors, nationally and globally (Bai \& $\mathrm{Ng} 2004$; Castagnetti, Rossi, \& Trapani 2017; Eberhardt \& Teal 2013). However, this issue has remained untouched in the literature on interest rate transmission. Ignoring the $\mathrm{CD}$ in these standard heterogeneous panel methods has most likely produced unreliable estimates with severe size distortions (Omay et al. 2017; Pesaran 2006).

Second, the effects of policy rates on bank interest rates have weakened since the GFC. ${ }^{1}$ This transmission breakdown is often interpreted as indicating changes in bank price-setting, but this view may be biased. Banks acquire funds from various sources, so their overall cost

\footnotetext{
${ }^{1}$ This transmission breakdown has emerged in Euro core advanced economies (Aristei and Gallo 2014; Hristov et al. 2014), and in Australia (Lim et al. 2013).
} 
of funds reflects the whole range of diverse liabilities (Fabbro \& Hack 2011). Recent global extreme shocks have induced a higher level of credit risk, liquidity risk, and competition, making the cost of market funding more expensive (ECB 2013). These significant changes in world financial markets violate the underlying assumption of an alignment between policy rates and retail interest rates (Naraidoo \& Raputsoane 2015).

This study examines heterogeneity and asymmetry in the transmission of the cost-of-funds rates, domestically and internationally, to home-loan interest rates, controlling for crosssection dependence. Our country selection has been made owing to the importance of Australian housing and housing finance markets from the perspectives of an effective monetary policy and wealth effects on consumption (Jansen 2013; Robstad 2018). Australia is one of the top five world largest mortgage markets, just standing behind Denmark, Norway, and Netherlands, whose ratios of total mortgage credit to annual economy output (GDP) are greater than 100\% (IMF 2017). Globally, Australia possesses the highest ratio of housing loans to total bank loans at $64 \%$, a ratio that has continuously increased since the GFC (IMF 2017). Its mortgage market is highly oligopolistic: the dominance of four major banks constitutes over 85\% of total market share (presented in Fig. B1, Appendix B). Only Australia, of these five, raises considerable mortgage funds from wholesale sources; the others source their funds mainly from domestic deposits. A significant portion, around $35 \%$, of Australia's mortgage funding is sourced from world financial markets (Ralston \& Davis 2011; Wilkins et al. 2016). This heavy reliance on foreign borrowings also poses a serious practical question for policy makers and banking regulators: housing finance markets with these characteristics are highly associated with house-price booms that potentially threaten financial stability, locally and internationally (Cerutti, Dagher, Ariccia, and Blanchard 2017).

Our pronounced contribution to the literature is the implementation of novel econometrics techniques. Our heterogeneous panel-data models, which build on the Augmented Mean Group (AMG) method (Bond \& Eberhardt 2013; Castagnetti et al. 2017; Eberhardt \& Bond 2009) and on the NARDL framework (Shin et al. 2014), facilitate the incorporation of common factors, heterogeneity, and asymmetry in model-setting. We apply the approach of Chudik and Pesaran (2015), which uses lags of the dependent variable as regressors in a dynamic setting. Both linear and nonlinear AMG models perform well in controlling for observed and unobserved common factors. ${ }^{2}$ We perform the models over the full-sample span for the banking sector and over three sub-groups: major, foreign, and region. The impact

\footnotetext{
2 The main advantages of the AMG model are discussed in Subsection 4.4 because of the space limitation of the introduction.
} 
of the crisis on this transmission is scrutinised in the sub-sample analysis: before, during, and after the GFC. We estimate the degrees of mortgage rate adjustments to changes in the cash rate and the foreign-funds rate for all models. We carefully test the CD properties of the dataset.

We employ a new exogenous variable, the foreign-funds rate, to supplement a new proxy for the cost-of-funds rates, along with the conventional use of the cash rate in the literature. The testable hypothesis, formed from the marginal cost-of-funds approach (De Bondt 2005), is that retail interest rates are set as a profit margin (markup) over the bank marginal funding cost. The overall cost-of-funds rate is mainly approximated from variations in funding costs because banks borrow from different sources. The existing literature typically uses policy rates or money market rates as the proxies for bank cost-of-funds rates. The rates that should be used for Australian banks, however, are the domestic and foreign-funds rates, due to their exceptional wholesale models of mortgage funds. Australia and South Africa (an emerging economy), the only countries amongst 53 sampled by Cerutti et al. (2017) that finance their mortgages from wholesale funding sources, accounting for only $0.038 \%$ of the Cerutti's et al. (2017) sample. The other 44 sampled developed and emerging countries, which account for $83.02 \%$, source their funds mainly from retail deposits. At an individual level, banks' significant exposure to international debt is anticipated to affect their mortgage price-setting policies. Our work empirically contributes hitherto unavailable evidence of the systematic nexus between international funds costs and mortgage interest rates.

This study also contributes to the development of the literature by employing a bank-level dataset of weekly variable home-loan interest rates. This high-frequency dataset, constructed from 20 anonymous Australian banks for the period 2002(7)-2015(12), enables researchers to eliminate the aggregation bias. Aggregating interest rate series can eliminate the possibility of heterogeneity in individual bank pricing behaviour, possibly resulting in biased results (De Graeve et al. 2007; Fuertes et al. 2010). Using a comprehensive disaggregated dataset offers more efficient estimated results; it also overcomes aggregation bias problems (detailed in Imbs et al. 2005).

We provide the first comprehensive bank-panel analysis of the mortgage IRPT, by considering cross-sectional dependencies in macro panel data, parameter heterogeneities and asymmetries. Our results affirm the presence of cross-sectional dependence in interest rate panels, heterogeneity, and asymmetry in the long-term pass-through. Most importantly, we find that the unobserved common factor is imposed on each bank. These findings have 
previously been unexplored in the literature on interest rate transmission, but our findings are consistent with the contemporary literature on growth and credit spreads (Castagnetti et al. 2017; Eberhardt \& Teal 2013). Incomplete heterogeneity and positive asymmetry have been significantly verified, reaffirming the market power hypothesis, and indicating variations in bank mortgage rate setting conduct. Remarkably, the mortgage rates have perpetually been adjusted greater upwards than downwards in response to foreign-funds rate hikes or cuts since the crisis, but they significantly decrease corresponding to cash rate cuts only. These novel findings validate our hypothesis that, since the GFC, bank price-setting has been closer to international funding cost movements than to the cash rate. These novel outcomes have important policy implications.

Section 2 reappraises the theoretical and empirical literature on heterogeneity and asymmetry in mortgage interest rate pass-through. Section 3 describes the sample and data, while Section 4 outlines the estimation strategy and models. Section 5 analyses the empirical results and Section 6 draws key conclusions and implications.

\section{Literature review}

We first briefly review two predominant theories, market concentration (Hannan \& Berger 1991) and competition (Kopecky \& Van Hoose 2012); we also review empirical support for rigidity in lending interest rate adjustments in the long term. Concentration theory posits that retail interest rates respond to market rate shocks more slowly in more concentrated markets due to collusion. Banks with greater market power can collude in pricing, resulting in upward rigidity in deposit rates and downward rigidity in lending rates, which favours lenders. Toolsema and Jacobs (2007) strongly propose that when banks adhere to a tacit collusive agreement, lending rates are asymmetrically stickier to decreases in policy and/or money market rates than to increases, resulting in positive asymmetry, even though an increase in input price is common knowledge because changes in market rates are transparent. Banks can make abnormal incomes as long as none reduces its price to a cost cut. Concentration theory is widely applied in the empirical literature on the transmission of changes in monetary conditions. Numerous studies in this strand confirm the existence of positive asymmetry in the pass-through of lending interest rates to policy rates or market rates for mortgage markets in the US (Allen, Rutherford, \& Wiley 1999), Canada (Allen \& McVanel 2009), the Netherlands (Toolsema \& Jacobs 2007), the UK (Fuertes et al. 2010), and Australia (Apergis \& Cooray 2015; Valadkhani \& Anwar 2012). 
The competition hypothesis postulates that highly competitive markets induce banks to reduce their mortgage rates quickly when policy and/or market rates decreases, but to increase the rates sluggishly when their funding cost rises. Banks encounter the fear of losing customers, so their reluctance to adjust their lending rates upwards results in negative asymmetry, which is preferable for mortgage borrowers. Several studies in Singapore (Chong, Liu, \& Shrestha 2006), New Zealand (Liu, Margaritis, \& Tourani-Rad 2011), the Netherlands and the US (De Haan \& Sterken 2011; Payne 2007) provide downward or negative asymmetry results supporting this customer-favourable hypothesis. Banks in these studies fiercely contest a product line in the same market segment, so are faster to reduce their housing rates downwards, but slower to increase these rates to preclude severe customer loss by accepting lower margins.

Our second critique focuses on the study of heterogeneity in the IRPT that evaluates the responsiveness of housing interest rates to monetary policies. Single- and cross-country studies have assessed the degrees of integration between housing interest rates and policy rates: in Australia (Liu et al. 2016; Sathye 2013), in the Euro area (Bernhofer \& Van Treeck 2013; De Bondt 2005; Hristov et al. 2014), and in a comparison of Australia and the US (Lim et al. 2013). The few studies employing bank-level data are confined to several advanced mortgage markets. In particular, De Graeve et al. (2007) take compatible maturity market rates as proxies for the cost-of-funds rates to investigate heterogeneity in Belgian bank pricesetting conduct. Other studies (Fuertes et al. 2010; Horváth \& Podpiera 2012) focus on how mortgage and other retail rates closely react to policy rate changes in the UK and the Czech Republic. Nonlinear ECM, VAR, panel cointegration, ARDL, and NARDL techniques are commonly used. These studies mostly yield incompleteness for all retail interest rates, as well as large variations in size and speed of short-term pass-through across different products and banks. The grounds for wide discrepancies in the short-term pass-through are significant differences in market concentration, credit risk, menu and switching costs, diversifications, market developments, and bank characteristics (De Bondt 2005; De Graeve et al. 2007; Fuertes et al. 2010; Horváth \& Podpiera 2012).

The constraint of having so little empirical literature on monetary transmission at the bank level is the lack of long-time disaggregated series on mortgage interest rates in datasets, because of the requirements for strict confidentiality in banking. The most major shortcoming in the existing literature is that cross-section dependence has been largely disregarded when estimating conventional panel-data models. Panel cointegration approaches based on the 
ECM and/or VECM, and the panel ARDL models are commonly used (e.g., Bernhofer \& Van Treeck 2013; De Graeve et al. 2007; Horváth \& Podpiera 2012; Illes, Lombardi, \& Mizen 2015). These methods, based on the assumption of cross-sectional invariants, disregard the presence of cross-sectional correlation in model setting so these studies document homogeneity in the mortgage rate pass-through in the long run. Sorensen and Werner (2006) pioneer controlling for cross-section dependence using the dynamic, seemingly unrelated, regression (DSUR) by Mark, Ogaki, and Sul (2005). However, their model requires a normal distribution of the residuals.

Internationally, the literature on interest rate pass-through using comprehensive bank-level mortgage rate datasets over a relatively long period remains scarce. We are unaware of any preceding study that considers the effect of foreign funding costs, so our study begins to explore the literature area. The studies reviewed examine heterogeneity or asymmetry (speed and/or short-run only) separately, without considering the cross-section dependence issue. We therefore shed light on this important area by controlling for cross-section dependence while simultaneously investigating heterogeneity and asymmetry in the long-term mortgage price-setting that relate to both cash rate and foreign-funds rate at the bank level.

\section{Sample and data description}

\subsection{Sample and data}

The data span of 13 years, 1 July 2002 to 31 December 2015, is obtained from an initial 18year bank-specific period because our econometrics techniques require a balanced panel sample. This period ranges over a number of recent financial crises (e.g., the GFC; the ensuing European debt crisis of 2010-2011), allowing capture of potential market structural changes. The unanticipated macroeconomic shocks have been confirmed to induce structural breaks and nonlinearity in the real interest rates for 17 OECD economies, including Australia (Omay et al. 2017). Our 20 anonymous samples including four major banks, three foreignowned subsidiaries, and 13 smaller Australian-owned banks provide approximately $90 \%$ of the total outstanding mortgages over the whole sample period (author's calculation). The representativeness of the selected banks is relatively well exemplified. We obtain a full balanced panel-sample of 20 banks and 706 weeks, after screening. Because of the oligopoly of the banking system, the original sample is subdivided into four subsets: sector, major, foreign, and region. Heterogeneous mortgage price-setting practices are thus expected. 
Our panel dataset has a longer time span $(T=706$ weeks $)$ than other disaggregated studies (e.g., Apergis \& Cooray 2015; De Haan \& Sterken 2011), allowing for splitting the full sample into three sub-spans (before, during, and after the crisis) to assess the impact of the GFC on the transmission. The breakpoint, 1 July 2007, is selected for the pre-crisis episode 2002(7)-2007(6) of 216 weeks. The bankruptcy of the New Century Financial Corporation in April 2007 triggered the US subprime mortgage crisis of 2007-2010. The Northern Rock downfall in September 2007 subsequently led to the British credit crisis, which strongly affected Australian bank price-setting conduct. Since the ensuing GFC, funding costs in global and Australian financial markets have significantly increased. We analyse bank pricesetting behaviour during the crisis 2007(7)-2009(12) of 131 weeks, and the post-crisis period 2010(1)-2015(12) of 314 weeks, separately due to crisis abnormality.

The weekly dataset employed uses the variable home-loan rates of 20 anonymous banks, the official cash rate, the policy rate in Australia, and the bank bill swap rate (BBSW). The effective home-loan rate variable, $E R$, is constructed from the annual adjustable percentage rate of mortgages covering all kinds of fees. To construct the comparable dataset, we select only standard adjusted rate mortgages with 25 to 30 years' maturity and the loan amount of A \$250,000 for owner occupiers. ${ }^{3}$ The weekly mortgage rates were commercially manually taken from Cannex's survey of Australian lenders (purchased by Griffith University). Two funding cost variables, $B B$ and $C R$, are retrieved from the Bloomberg terminal at Griffith University. The 3-month A\$ BBSW, a key unsecured short-term money market benchmark used globally, ${ }^{4}$ acts as a better proxy for the foreign-funds rate variable, $B B$, than the US\$ LIBOR. The A $\$$ BBSW is typically referenced when Australian banks source their foreign funds in both onshore and offshore financial markets; LIBOR is a benchmark rate for offshore issues only (Guttmann \& Rodgers 2015; RBA 2006). Technically, using the A\$ BBSW eliminates possible calculation errors from currency conversion. Although Australian banks' overseas debt is mostly denominated in US dollars, it is swapped into fixed or floating home currency contracts through foreign exchange swaps and/or currency swaps to hedge against the currency risk (Turner \& Nugent 2015). The cash rate, $C R$, is widely used in the

\footnotetext{
${ }^{3}$ Owner-occupied loans indicate the value of housing loans to Australian households for the construction or purchase of dwellings for owner occupation; revolving credit or redraw facilities are originally approved for the purpose of predominantly owner-occupied housing (APRA 2017).

${ }^{4}$ The 3-month BBSW, which represents the midpoint of the nationally observed best bid and best offer for AFMA Prime Bank Eligible Securities, including bank accepted bills and negotiable certificates of deposit, is used to provide reference interest rates for the pricing and revaluation of Australian dollar derivatives and debt securities.
} 
IRPT literature as the exogenous policy rate because it is a direct measure of monetary policy stances and a key mainstream funding indicator.

\subsection{Data description}

The pairwise cointegration test substantiates well-cointegrated relationships between nexuses $E R_{\mathrm{t}}-B B_{\mathrm{t}}$ and $E R_{\mathrm{t}}-C R_{\mathrm{t}}$ at 0.85 . Two exogenous cost-of-funds rate variables, $B B_{\mathrm{t}}$ and $C R_{\mathrm{t}}$, are likely to have perfect multicollinearity at 0.98 . Two variables can behave individually, as nonstationary random walks, because interest rate series are dominated by smooth, long-term trends. Econometrics procedures hereafter have been conducted separately for each nexus, to eliminate spurious estimated results.

Standard procedures for macro panels commence with descriptive statistics (see Table B1, Appendix B) disclosing relatively interesting information. The mean statistics indicate that both major and region banks ask relatively lower prices for home loans than the sector. The foreign group charges the most expensive average price for mortgages, while the regional banks offer the most competitive rate for their mortgage borrowers. However, the foreign group is the most stable in mortgage rate setting, while the region banks are the most volatile during the full-sample or sub-sample spans. The average price of foreign funds is relatively greater than the average price of domestic borrowings. The former is also more volatile than the latter. We use the Bartlett mean equality test to compare the means for pre-GFC, GFC, and post-GFC periods. The test results are reported in the last column of the table. Bartlett's test is prominently employed to test simultaneously for the equality of more than two means, while other tests compare two means at a time. The statistically significant chi-squares tests ascertain a statistical difference in the mean values of each of the variables across the three sub-periods, indicating the presence of structural breaks in the series, consistent with Omay et al. (2017).

Fig. B2 in Appendix B draws a visual inspection of any possible co-movement between mortgage rates and cost-of-funds rates. The evidence of this potential interaction appears clearly perceptible for both cash rate and foreign funding cost, given a sharp plunge during the GFC. Virtually all sampled banks revealed a strong positive cointegration between mortgage rates and the cost-of-funds rates. The figure also signifies the cross-section dependence properties of the panels. We have empirically tested this problem in Subsection 4.2 to preclude severe biased estimates and incorrect inference in the standard panel estimators, that is based on the assumption of cross-section independence (Pesaran 2006). 


\section{Estimation procedure}

\subsection{Theoretical marginal cost pricing model}

De Bondt (2005) formally exposed the marginal cost pricing $\operatorname{model}^{5}$ for determining retail interest-rate pass-through under imperfect market competition. A bank interest rate based on this approach is determined as a constant markup over the overall funding cost, as follows:

$$
b r=\beta m r+\mu
$$

where $b r$ refers to the bank interest rate, and $m r$ is the exogenous cost-of-funds rate. The size of the long-term pass-through coefficient, $\beta$, tends to be close to unity when adjusting to the equilibrium. The constant markup, $\mu$, is appropriated by numerous elements affecting bank price-setting at the individual level, including demand side, competition, risk premia, and bank characteristics such as size, capitalisation, and liquidity (Freixas \& Rochet 2008). Study of the influencing factors forms the determinant strand of the literature on monetary policy transmission, such as Fiszeder and Pietryka (2017) and Naraidoo and Raputsoane (2015).

The funding cost, which constitutes the most substantial determinant of bank price-setting, determines the pass-through magnitude. This marginal cost-of-funds rate attributes mainly to the availability of funding sources or close substitutes to banks, the availability of financial alternatives to borrowers, and the market power that affects the elasticity of demand for bank lending products (De Bondt 2005). The study of heterogeneity and asymmetry, in the transmission of the cost-of-funds rate to bank interest rates examining the responsiveness of retail interest rate adjustments to monetary policies, universally adopts this marginal cost pricing model. The empirical studies of heterogeneity and asymmetry in the pass-through have been mainstreamed in the literature on monetary transmission because bank lending rates constitute a core element of this mechanism. This paper is in line with these strands.

The selection in the literature of the exogenous cost-of-funds rate variable, $m r$, depends on individual study's focus. Studies adopting the monetary policy approach (MPA) focus solely on capturing the effect of monetary policy on retail interest rates, so administered policy rates or short-term interbank rates act as proxies for the exogenous cost-of-funds rates. The costof-funds approach (CFA) emphases banks' price-setting decisions, taking money market rates of compatible maturities to retail bank rates. This method theorises that the market rates represent banks' funding costs, when raising funds from various sources in money markets, and opportunity costs in capital markets. Both MPA and CFA approaches employ only an administered policy rate or a short-term interbank rate or a compatible market rate as the

\footnotetext{
${ }^{5}$ This model is based on the mark-up pricing contribution of Rousseas (1985)
} 
proxy for the exogenous cost-of-funds rate in the bivariate models, without including other explanatory variables. Several researchers adopt both approaches (e.g., Égert et al. 2007; Sander \& Kleimeier 2004). We follow the literature, incorporating the cash rate and the $\mathrm{BBSW}$ as the proxies for domestic and foreign funding costs.

\subsection{Model selection tests}

\subsubsection{Cross-sectional dependence and homogeneity tests}

Breusch and Pagan's (1980) LM test is not workable to detect cross-sectional dependence for panel data with large cross sections, $N>10$ (Pesaran 2015). The Pesaran (2004) CD test replaces this LM test for large panels, where $T \rightarrow \infty$ first and then $N \rightarrow \infty$ under the null hypothesis of cross-section independence. This test has several pronounced features: it performs well for static and dynamic models, for balanced and unbalanced panels, and even for a miniature sample with five cross sections $(N=5)$. Pesaran's (2004) test enables not only the detection of global cross-sectional dependencies, but also the satisfactory examination of local cross correlations for macro panels with long time dimension $(T \rightarrow \infty)$. The most advantageous feature of this test is its ability to conquer the cross-sectional dependence in the presence of structural breaks, both single and multiple, in data without size distortions. Our dataset, which encompasses a wide range of extreme global financial distress, is highly subjected to structural breaks, signifying the presence of nonlinearity. Our panel dataset has 20 banks $(N=20)$ and large time dimensions $(T=706)$ : Pesaran's (2004) CD test is a practicably appropriate method for this study because sizable distortions may occur only when applying this test for panel-data models with large $N$ and short $T$.

Conduct a slope homogeneity test is necessary to select a practicable cointegration test. Since our panel has large $T$ and small $N$, we adopt the Swamy LM test because Pesaran and Yamagata's (2008) test is workable for panels only if the cross sections are relatively similar in size to the time dimensions. The null hypothesis of slope homogeneity is rejected, corresponding to a large chi-square statistic, indicating the existence of slope heterogeneity.

\subsubsection{Panel unit root and cointegration tests}

This study uses the cross-section augmented Im-Pesaran-Shin (CIPS) test of Pesaran (2007), extended by Pesaran, Vanessa Smith, and Yamagata (2013). Among the second-generation panel unit root tests, the CIPS and the Panel Analysis of Nonstationarity in Idiosyncratic and 
Common components (PANIC) procedure of Bai and Ng $(2004,2010)$ have most prevalently outperformed their rivals in controlling for cross-section dependence (Pesaran et al. 2013). The former has quickly monopolised the contemporary literature owing to its simplicity of implementation, whereas the latter motivates more theoretical extensions because it is the more arguable approach. The PANIC approach, however, can produce distorted estimations when sample sizes are small $(N \leq 20)$, while the CIPS test performs superlatively for small sample sizes (Reese \& Westerlund 2016). Because our panel has 20 cross sections, we follow the empirical literature, adopting the CIPS to test for panel unit roots in the presence of the cross-section dependence properties of the data and diagnostics.

We employ the Westerlund (2007) panel cointegration test with robustness for crosssectional dependence and slope heterogeneity. This technique capably accommodates not only unit-specific short-term dynamics, unit-specific trend, and slope parameters, but also cross-section dependence. We account robustly for cross-section correlations and obtain mostly significant results.

\subsection{Model selection decision}

The results of the Pesaran (2004) CD test and the LM homogeneity statistics are reported in Panels A and B, Table A1 in Appendix A. The null hypothesis of cross-section independence is significantly rejected at the $1 \%$ level for each variable on level and at first difference, firmly confirming the existence of the cross-section dependence in the panels. The significant and large LM statistics signify no slope homogeneity. Our panel data are strongly crosssectionally correlated and slope heterogeneous based on these test results.

Table A2 shows the CIPS test results for all groups. We use a maximum number of 8 lags to determine the optimal lag length and serial correlation order. The CIPS results ascertain the stationarity of the mortgage rate variable on level for all groups. However, the results for two funding rates are mixed. The test signifies that the foreign-funds rate and cash rate are integrated at order one, suggesting that the cross-section correlations are heterogeneous based on these funds rates. The CIPS results show that the dependent variable ER is $I(0)$, while the exogenous variables all become stationary at $I(1)$, so we can perform the cointegration test.

We estimate the robust p-value through 800 times of bootstrapping to control for possible bias due to the presence of the cross-section dependence. The cointegration test results in Table A3 indicate most significant rejection of the no cointegration null hypothesis with the foreign-fund rate estimates. However, the group-mean cointegration could not prevail among 
all cash rate estimates, indicating that these banks have similar speed of adjustments to the long-run equilibrium. The results suggest that, to a certain extent, bank re-pricing is still subject to cash rate developments.

Overall, these preliminary tests strongly suggest the selection of a dynamic heterogeneous panel-data model based on a common-factor framework. This model can concurrently address the inherent cross-section dependence and nonstationarity of the macro panel data, as well as heterogeneity and asymmetry in the transmission for this analysis.

\subsection{Empirical AMG models}

Our dynamic heterogeneous panel-data models for linearity (symmetry) and nonlinearity (asymmetry) build on a common-factor AMG method (Bond \& Eberhardt 2013; Castagnetti et al. 2017; Eberhardt \& Bond 2009). This approach allows the capture of bank-specific disparities in mortgage pricing in the presence of observable and unobservable common components in panel data. Theoretically, cross-sectional correlations can arise from both observed and unobserved common factors, nationally and globally. Unanticipated shocks, such as the GFC, national tax cuts, or the Australian Prudential Regulation Authority (APRA)'s implementation of the Basel III capital reforms on 1 Jan 2013, unavoidably influence our sampled-bank operations and trigger wide discrepancies in mortgage pricesetting, due to the sampled banks' heavy reliance on foreign funds and their international operations. Extreme global shocks also induce asymmetry in mortgage price-setting in the long run, as confirmed by Apergis and Cooray (2015).

Owing to the novel advantages of the AMG estimator, it is selected from the common correlated effect mean group (CCE) estimator (Pesaran 2006) and the dynamic CCE (DCCE) estimator (Chudik \& Pesaran 2015), the innovative common-factor models for macro panel data. Both the AMG and DCCE models build on the CCE approach to accommodate variable nonstationarity, parameter heterogeneity, and cross-sectional dependence, but the DCCE is highly subject to small-sample bias in a dynamic specification (Chudik \& Pesaran 2015). The AMG estimator contains the inherent strengths of the CCE model, which effectively performs (a) observables and unobservables, (b) potential linearity and nonlinearity, (c) in the presence of idiosyncratic and global business cycles, (d) for panel-data models with the small crosssection dimension, and (e) nonstationary, cointegrated, or non-integrated variables (Kapetanios, Pesaran, \& Yamagata 2011). The AMG method differs from the CCE estimator: it incorporates an explicit estimate for unobservables providing meaningful economic 
interpretation. If coefficients on the common dynamic process statistically and homogenously equal unity, unobservables are imposed on each group. The AMG estimator, which capturing idiosyncratic time-varying unobservables by including a time-trend term in the model-setting, enables researchers to appropriately solve the information available in our dataset either the existence of nonlinearity, structural breaks, or cross-sectional dependence.

\subsubsection{Linear dynamic AMG}

We produce the main models with a multifactor error structure to honour space limitation. First, given the importance of time-series properties in macro panel data, the dynamic heterogeneous panel-data model for Eq. (1) is formalised as

$$
y_{i t}=\alpha_{o i} y_{i t-1}+\beta_{1 i} \operatorname{cash}_{i t}+\beta_{2 i} \text { fund }_{i t}+u_{i t}
$$

where y denotes the mortgage rate, $E R$, cash and fund are the cash rate, $C R$, and foreignfunds rate, $B B$, in this analysis. Two exogenous funding costs variables comprise the observable parts of our model, with their parameters $\beta_{i}$ allowed for bank-specific disparities. This heterogeneity is the major focus of this empirical analysis. Parameter $\alpha_{o i}$ is the structure estimator. If this parameter is set equal to zero, the dynamic model will be transformed into a static form. The subscripts $i(i=1, \ldots, N)$ and $t(t=1, \ldots, T)$ indicate banks and weeks, respectively. The unobservable error term is $u_{i t}$.

The unobservables in Eq. (2) are simulated as $u_{i t}=\alpha_{1 i}+\lambda_{i^{\prime}} \boldsymbol{f}_{t}+\varepsilon_{i t}$. The linear equation for the symmetry analysis of the nexus between mortgage rates and funds rates, controlling for the unobservables, is specified as follows:

$$
y_{i t}=\alpha_{o i} y_{i t-1}+\beta_{1 i} \operatorname{cash}_{i t}+\beta_{2 i} \text { fund }_{i t}+\alpha_{1 i}+\lambda_{i^{\prime}} \boldsymbol{f}_{t}+\varepsilon_{i t}
$$

Eq. (3) incorporates bank-specific intercepts $\left(\alpha_{1 i}\right)$, a multiple-structure of unobserved common factors $\boldsymbol{f}_{t}$ with group-specific factor loadings $\lambda_{i^{\prime}}$ to capture time-variant heterogeneity and cross-sectional dependence. The assumed white noise is $\varepsilon_{i t}$. A time-trend term can also be included in the model, but in our case this variable is insignificant. The constant markup, $\alpha_{1 i}$, and long-term pass-through coefficients, $\beta_{i}$, are expected to have positive signs because, in the long term, market rate developments are fully transmitted into bank retail rates.

\subsubsection{Nonlinear dynamic AMG}

The nonlinear AMG model for the asymmetry analysis is obtained by incorporating the decomposing procedure of the NARDL approach (Shin et al. 2014) into the AMG 
framework. Eberhardt and Presbitero (2015) have identically adopted this method to form their asymmetric DCCE estimator. The NARDL modelling approach is ideal for the passthrough study because it inventively divides changes in exogenous variables into partial positive and negative sums of process. This setting, which enables researchers to capture size asymmetry, differs from the ECM, which allows measurement of asymmetry in adjustment speed only. This approach has quickly become common usage in the literature on the passthrough mechanism (e.g., Apergis \& Cooray 2015; Brun-Aguerre, Fuertes, \& GreenwoodNimmo 2017).

Following Eberhardt and Presbitero (2015), our nonlinear AMG equation builds on the linear AMG and NARDL approaches, with the assumption of nonstationary observed and unobserved variables. We first decompose the exogenous variables into the partial sum decomposition of either the foreign-funds rate or the cash rate as $m r_{i t}=m r_{i 0}+m r_{i t}^{+}+m r_{i t}^{-}$. The initial value $m r_{i 0}$ can be set to 0 . The latter two terms are positive and negative partial sums of processes, corresponding to increases and decreases in mortgage funding costs for each bank. These partial sum processes of funding cost rises, $m r_{i t}^{+}$, and funding cost cuts, $m r_{i t}^{-}$are accumulated as

$$
m r_{i t}^{+}=\sum_{j=1}^{t} \Delta m r_{i j}^{+}=\sum_{j=1}^{t} \max \left(\Delta m r_{i j}, 0\right), \quad m r_{i t}^{-}=\sum_{j=1}^{t} \Delta m r_{i j}^{-}=\sum_{j=1}^{t} \min \left(\Delta m r_{i j}, 0\right)
$$

The dynamic AMG version of our asymmetric model is specified as

$y_{i t}=\alpha_{o i} y_{i t-1}+\beta_{1 i}^{+} \operatorname{cash}_{i t}^{+}+\beta_{1 i}^{-} \operatorname{cash}_{i t}^{-}+\beta_{2 i}^{+}$fund $_{i t}^{+}+\beta_{2 i}^{-} f_{u n d}^{-}+\alpha_{1 i}+\lambda_{i^{\prime}} \boldsymbol{f}_{t}+\varepsilon_{i t}$

where $\beta_{i}^{+}$and $\beta_{i}^{-}$are the asymmetric long-run parameters and these coefficients are theoretically positive.

\section{Estimation analysis}

\subsection{Empirical results}

Tables 1 and 2 present the linear AMG results of the full and sub-sample estimates for four sampled groups: sector, major domestic, foreign subsidiary, and region or smaller domestic in successive columns. The nonlinear AMG results are reported in Tables 3 (full sample) and 4 (sub-sample). Both static and dynamic AMG models are performed for all linear and nonlinear estimates. The full-sample results, both static [1] and dynamic [2], are shown in Tables 1 and 3. We report only the dynamic results of the sub-sample estimates in Table 2 (symmetry) and Table 4 (asymmetry) due to space limitation, but the static results is available 
upon request. In each table, Panel A reports the estimated results of the mortgage-foreign funds rate nexus and Panel $\mathrm{B}$ shows the mortgage-cash rate nexus.

Regarding the goodness of fit for two full-sample estimates (Tables 1 and 3), the major and foreign produce significantly smaller root mean square errors (RMSE) than the sector and region. The RMSE of the dynamic specifications are slightly fewer than those of the static RMSE, indicating that the dynamic estimates are more workable for the major and foreign. This implies that the two groups have more market power to exert price-setting disparities. The static models, in contrast, work sufficiently for the region with the smaller RMSE, resulting in the analogous result for the sector, signifying the homogeneity in their price-setting. Of the sub-sample estimates, the dynamic AMG yields many fewer RMSE than the static specification (see Tables 2 and 4), validating the greater efficiency of the dynamic estimator in this study. Virtually all estimates significantly pass the nonstationary residual test. The CIPS diagnostic test results strongly statistically affirm the rejection of the nonstationary residual hypothesis, indicating that the selected estimators are sufficient to eliminate spurious regressions. The coefficients on the lagged dependent variables are positive and statistically significant in all estimations, signifying a high level of model persistence. The estimated coefficients and constants have correctly positive signs. Overall, the linear and nonlinear AMG estimators, both static and dynamic, perform well.

The coefficients of the common dynamic process are positive and statistically significant at the $1 \%$ level for all full-sample estimates, regardless of whether the static or dynamic, linear or nonlinear models. The magnitudes of this coefficient for linear and nonlinear specifications consistently equal unity, indicating that the unobservables are imposed on each individual and their sizable influence on the transmission. The results still hold for the subsample estimates, except for the pre-crisis cash-rate estimates of the foreign group. Prior to the GFC, foreign banks may operate relatively independently so local shocks have negligible impacts on their price policies, while the national shocks strongly affect domestic banks' repricing. Our results suggest that, since the crisis, bank mortgage pricing has been significantly affected by unobservable national and global shocks. These findings affirm that the unanticipated shocks, which produce cross-sectional correlations in macro panel data, have substantial impact on the IRPT. Our novel findings show that the study of the IRPT employing the conventional panel-data models can produce insufficient empirical results because the cross-section dependence and nonstationary residuals are uncovered and 
insufficiently treated. These findings also motivate our further assessment of pass-through determinants.

\subsection{Symmetric pass-through analysis}

The results of both static and dynamic estimates in Table 1 confirm the substantial effects of the foreign-funds rate and of the cash rate on mortgage price-setting for Australian banks. All slopes of the foreign-funds rate estimates are statistically significant at the $1 \%$ level and are much greater than zero, substantiating the significant relationship between bank mortgage rates and international funding costs. The significant coefficients in the cash rate estimates reaffirm the alignment of the cash rate and mortgage rate, consistent with the literature (e.g., Lim et al. 2013; Sathye 2013). Our results ascertain the existence of heterogeneous long-term pass-through, which differs from the conclusion of long-term homogeneity in the literature (e.g. Bernhofer \& Van Treeck 2013; De Graeve et al. 2007; Illes et al. 2015), which use the conventional panel-data models with the assumption of the cross-sectional independence. Our finding suggests that, at the individual level, banks yield strong discrepancies in mortgage price-setting. The magnitude results show that the mortgage rates have rapidly moved toward the long-term equilibrium of $0.65-0.80$ accordingly funds rate changes, which is consistent with prior studies (Lim et al. 2013; Sathye 2013). These results specify that, for the long run, a $1 \%$ change in the cash rate or international funding cost would be incompletely transferred into the mortgage rates between $0.65 \%$ and $0.80 \%$. The region and sector groups produce similar pass-through degrees, while the major and foreign banks show slightly greater coefficients for both foreign-funds rate and cash rate estimates. Our finding of incomplete long-term pass-through, which is in line with the conventional literature, is typically theoretically explained by variations in bank market power, competition, and menu costs.

[Insert Table 1 about here]

We further estimate separately the three sub-periods, pre-GFC, GFC, and post-GFC, for each bank group to deeply assess the crisis effect on the funding cost transmission. The results of the linear dynamic AMG estimates in successive columns of Table 2 still significantly reaffirm the sizable influence of the unobservables on the transmission for each group.

\section{[Insert Table 2 about here]}

Most slope coefficients are statistically significant at the $1 \%$ and $5 \%$ levels for both cash rate and foreign-funds rate estimations, reaffirming the established relationships. The subsample estimates reveal interesting results. Before the crisis, all groups completely 
transmitted foreign-funds rate changes to their mortgage rates. The pre-GFC slope parameters, are greatest in size, and are significantly larger than those of the full-sample, during, and post-crisis estimates. The cash rate transmission is nearly complete, consistent with existing studies using disaggregated data (Fuertes et al. 2010; Horváth and Podpiera 2012). These results indicate that the responsiveness of mortgage rates to cash rate changes is strongest before the crisis. Our finding validates the effectiveness of the monetary transmission in normal economic conditions because the underlying assumption of parallel movements between policy rates and retail interest rates holds only when central banks strongly exert control over money market rates. The magnitudes of the foreign-funds rate coefficient are relatively greater than those of the cash rate, indicating that banks are more responsive to their international funding cost. This finding is consistent with Lim et al (2013); these authors suggest that, prior to the crisis, the cash rate was set closer to macroeconomic purposes than to banks' funding indicator.

During and after the crisis, the slopes of both foreign-funds rate and cash rate significantly decrease for all estimates, while the markups dramatically increase. The results confirm the impairment of the cash rate transmission, implying that banks appear reluctant to follow the cash rate cycle after the crisis. The much greater markups specify that Australian banks have encountered higher risk when sourcing in the world financial markets because this markup measures competition, market risk premium, and regulatory factors (De Bondt 2005). The strongest decline in both cash rate and foreign-funds rate transmission has occurred in the region group since the GFC, especially the post-crisis estimated insignificance. Their lowest coefficients are attributable to the poor results of the sector. Both major and foreign banks have produced a decline in their cash rate transmission, but their declining pace is slight and much lower than that of the region. The comparable decline in the foreign-funds rate transmission occurs in the foreign group, but this transmission of the major banks has significantly improved since the GFC. Since the crisis, the incomplete pass-through has been found for all sampled groups. These rigid findings are analogous to those of the full-sample estimates and the literature. Thus, our findings propose solid evidence for the substantial effect of the CFC on mortgage re-pricing behaviour in Australia.

The presence of heterogeneity and rigidity is commonly explained by the highly concentrated market hypothesis. In this market, banks are able to exert their market power over mortgage borrowers to a certain extent, resulting in the incomplete pass-through. The Australian finance system is highly oligopolistic, similar to the British, Czech, and Dutch 
markets that reveal similar patterns of incomplete IRPT mechanism. Our results are in line with De Graeve et al. (2007) and Fuertes et al. (2010), who document that the sampled banks are reluctant to adjust their mortgage rates due to market structure, adjustment and switching costs. Our sub-sample analysis affirms the transmission breaks that are highly consistent with the recent studies, locally (Lim et al. 2013; Liu et al. 2016; Sathye 2013) and worldwide (Aristei and Gallo 2014; Hristov et al. 2014). One plausible reason for this breakdown is the decline in market competition since 2007 due to a noticeable increase in market concentration with the dominance of the Big-4 (see Fig. B1). The impairment and rigidity in pass-through also give an earlier indication of asymmetry in the transmission.

\subsection{Asymmetric pass-through analysis}

Table 3 presents in consecutive columns the asymmetric results of both static and dynamic AMG estimates for each group over the full-sample period. Wald test results in both static and dynamic nonlinear estimates are consistently significant at the $1 \%$ level, confirming the existence of long-term asymmetry. Once again, the nonlinear results strongly reaffirm the significant impact of the unobservables on the transmission.

[Insert Tables 3 about here]

We focus on analysing the asymmetric results of the observables in the long run. The positive and negative long-run coefficients associated with increases and decreases in the foreign-funds rate are all highly significant at the $1 \%$ level and have correct signs, signifying a direct relationship. The positive coefficients are all greater in size than the negative ones in all estimates, confirming the presence of long-term downward asymmetry. This finding indicates that banks pass on more funding cost hikes, but transmit fewer the cost cuts into their mortgage rates, consistent with Apergis and Cooray (2015). Our finding of positive asymmetry validates the concentration hypothesis that banks in an oligopolistic market wield a certain extent of market power in price-setting. The long-run effect in absolute value of the funding cost rises on mortgage rates is more pronounced than that of the cost cuts for all groups. The asymmetric degrees of mortgage rates in response to cash rate are substantially larger than to the foreign-funds rate. The sector, for example, has a spread of positive and negative cash-rate coefficients at $0.345 \%$, compared with $0.094 \%$ in the foreign-funds rate. This finding supports the topical publicity and political debate that banks profit themselves from the exertion of their mortgage borrowers corresponding to cash rate cuts. Banks' homeloan rate-setting based on cash rate movements is the most closely watched in Australia, where outstanding home loans equate with $60 \%$ of GDP. Asymmetric mortgage pricing 
downwards affects consumer wellbeing significantly (Jansen 2013); poses a real threat to households because mortgagors pay interest charges directly from their disposable income, as these costs are not tax-deductible.

[Insert Tables 4 about here]

We conduct the nonlinear AMG model for each sub-period of each group to further examine the GFC effect on bank mortgage pricing. The results in Table 4 once again reaffirm the significant influence of the unobservables, except that the post-crisis cash-rate estimate for the foreign group is consistent with the sub-sample symmetry finding. The observable coefficients provide auspicious results for both funds rates. Prior to the crisis, banks significantly passed on funding cost increases only. The cash rate pass-through degrees are closer to unity and much larger than the foreign-fund rate transmission, supporting the symmetry findings. We find the positive response of mortgage rates to the cash rate only, because in this period the policy rate constantly increases. Since the GFC, mortgage rates have been continuously associated with foreign-funds rate developments, consistent with Cifarelli and Paladino ( 2016). Banks have asymmetrically priced their mortgages upwards at high levels. These coefficients are equal or closer to unity in all GFC and post-GFC estimates. Positive impacts are much greater in size than negative impacts. Variations in magnitudes exist in both positive and negative parameters, signalling downward rigidity or positive asymmetry. Our results substantiate that international funding costs have had stronger impact on mortgage rates since the crisis, indicating that bank mortgage price-setting has been closer to foreign-funds rate movements. Our findings empirically support the view of Berkelmans and Duong (2014), and provide empirical evidence of the increasing reliance of Australian banks on foreign funds to finance their mortgages.

Conversely, the cash rate estimates show opposite results. We still find positive asymmetry in mortgage rate pass-through during the crisis. These positive coefficients associated with cash rate rises are greater in size than the negative parameters. These positive slopes are all much larger than unity, indicating an overshooting response. This finding is in line with Lim et al. (2013) that banks set their higher mortgage rates to compensate for higher risk incurred. Interestingly, we find that all bank groups no longer responded to cash rate increases in the aftermath of the crisis. The post-crisis estimates yield insignificant and negligible positive coefficients. However, these banks significantly reduce their mortgage rates corresponding to cash rate cuts. This finding is inconsistent with the finding by Apergis and Cooray (2015), who document the existence of positive asymmetry in interest rate pass- 
through for Australia after the GFC. Our findings again support the theory of Eberhardt and Bond (2009), Omay et al. (2017), and Pesaran (2006) that the conventional methods used in the literature can produce highly biased and spurious results due to the lack of attention to cross-sectional dependence and nonstationary residuals untreated.

\section{Conclusions}

This study examines heterogeneity and asymmetry in the transmission of foreign funds and cash rates to mortgage rates for the period 2002(7)-2015(12), using a novel weekly dataset of 20 Australian banks. The innovative common-factor AMG and NARDL models are employed to examine heterogeneity and asymmetry in controlling for the cross-sectional dependence properties of the panel data. We also investigate the GFC effect on the transmission in a sub-sample analysis.

We provide the first comprehensive bank-panel analysis of the mortgage IRPT that considers cross-sectional dependence, heterogeneity, and asymmetry. Controlling for the cross-sectional dependence properties of the panel data, we find that the unobservables have significantly sizable influence on the transmission of both foreign-funds rate and cash rate. Our results of the estimated observables suggest that Australian banks asymmetrically set their mortgage interest rates in a heterogeneous manner. Heterogeneity and asymmetry in the mortgage rate pass-through are found for all panel estimates. The existence of the varied heterogeneous responses across banks indicates significant differences in mortgage pricesetting. These findings affirm the market power hypothesis. The sub-period analysis found a declining influence of the cash rate on mortgage rate traverses after the GFC although the effect of the international funding cost has been increasing. Our finding validates the argument that the divergence of bank mortgage price-setting from the cash rate shifts due to foreign funding cost.

This study provides three important policy implications. First, our findings provide empirical evidence of the strong integration between mortgage rates and foreign funding cost and of the decreasing reliance on the cash rate since the crisis. This evidence is of practical use to depository regulators, APRA and RBA, in implementing non-conventional monetary policy reforms. The regulators also need to pay close attention to the volatility of world finance markets when setting their policy rates. Second, it is critical for the RBA to construct a more properly comprehensive measure of the funding costs underlying mortgage interest rates. Our focus of the $B B$ measure in this analysis exemplifies only the foreign-funds rate. 
Further examination would require a more comprehensive measure of overall bank funding costs by constructing a weighted average cost of debt because bank liabilities are obtained from varied sources. Third, solid evidence that long-run positive asymmetry exists among the all sampled banks signals a series of consumer protection solutions that need to be put into effect. 


\section{Data and computer code availability:}

The datasets of this paper (1. code and programs, 2. data, 3. detailed readme files) are collected in the electronic supplementary material of this article.

The data that support the findings of this study are available from [CANNEX]. Restrictions apply to the availability of these data, which were used under license for this study, and so are not publicly available. However, instructions for how other researchers can obtain the data, and all the information needed to proceed from the raw data to the results of the paper (including code), are available from the authors upon reasonable request and with permission of [CANNEX].

\section{Acknowledgements}

The authors wish to acknowledge the constructive advice, useful comments and helpful suggestions given to us by two anonymous journal reviewers, and by participants at the Lunchbox seminar-PhD edition held by Griffith Environmental Futures Research Institute on Sep 15 2017, at the Social and Affordable Housing Symposium held by Griffith University in Brisbane, Australia on September 25 2017, and at the Campus for Finance -WHU New Year's Conference 2018, Jan 17-18 in Koblenz, Germany. We are responsible for any error or omissions remained. 


\section{References}

Allen J, McVanel D (2009) Price movements in the Canadian residential mortgage market. Bank of Canada Working Paper No. 2009-13.

Allen MT, Rutherford RC, Wiley MK (1999) The relationships retween mortgage rates and capital-market rates under alternative market conditions. Journal of Real Estate Finance and Economics 19(3):211-221. doi:10.1023/A:1007880410406

Apergis N, Cooray A (2015) Asymmetric interest rate pass-through in the U.S., the U.K. and Australia: New evidence from selected individual banks. Journal of Macroeconomics 45:155-172. doi:10.1016/j.jmacro.2015.04.010

APRA (2017) Monthly banking statistics. Australian Prudential Regulation Authority Publishing APRAWeb. http://www.apra.gov.au/adi/Publications/Pages/monthlybanking-statistics.aspx. Accessed 5 January 2017

Aristei D, Gallo M (2014) Interest rate pass-through in the Euro area during the financial crisis: A multivariate regime-switching approach. Journal of Policy Modeling 36:273295. doi:10.1016/j.jpolmod.2013.12.002

Australian Bureau of Statistics (ABS) (2017) Australian National Accounts: Housing Finance, May (5609.0). Canberra.

Bai J, Ng S (2004) A PANIC attack on unit roots and cointegration. Econometrica 72(4):1127-1177. doi:10.1111/j.1468-0262.2004.00528.x

Bai J, Ng S (2010) Panel unit root tests with cross-section dependence: A further investigation. Econometric Theory 26(4):1088-1114. doi:10.1017/S0266466609990478

Berkelmans L, Duong A (2014) Developments in banks' funding costs and lending rates. RBA Monthly Bulletin March:69-76.

Bernhofer D, Van Treeck T (2013) New evidence of heterogeneous bank interest rate passthrough in the euro area. Economic Modelling 35:418-429. doi:10.1016/j.econmod.2013.07.020

Bond S, Eberhardt M (2013) Accounting for unobserved heterogeneity in panel time series models. Discussion Paper, Nottingham, UK.

Brun-Aguerre R, Fuertes AM, Greenwood-Nimmo M (2017) Heads I win; tails you lose: asymmetry in exchange rate pass-through into import prices. Journal of the Royal Statistical Society. Series A: Statistics in Society 180(2):587-612. doi:10.1111/rssa.12213

Castagnetti C, Rossi E, Trapani L (2017) A two-stage estimator for heterogeneous panel models with common factors. Econometrics and Statistics 0:1-20. doi:10.1016/j.ecosta.2017.10.005

Cerutti E, Dagher J, Ariccia GD, Blanchard O (2017) Housing finance and real-estate booms: A cross-country perspective. Journal of Housing Economics. doi:10.1016/j.jhe.2017.02.001

Chong BS, Liu MH, Shrestha K (2006) Monetary transmission via the administered interest rates channel. Journal of Banking \& Finance 30(5):1467-1484. doi:10.1016/j.jbankfin.2005.03.024

Chudik A, Pesaran MH (2015) Common correlated effects estimation of heterogeneous dynamic panel data models with weakly exogenous regressors. Journal of Econometrics 188(2):393-420. doi:10.1016/j.jeconom.2015.03.007

Cifarelli G, Paladino G (2016) Time-varying mark-up and the ECB monetary policy transmission in a highly non linear framework. International Review of Economics \& Finance 45:247-262. doi:10.1016/j.iref.2016.06.001

De Bondt GJ (2005) Interest rate pass-through: Empirical results for the Euro area. German Economic Review 6(1):37-78. doi:10.1111/j.1465-6485.2005.00121.x 
De Graeve F, De Jonghe O, Vennet Vander R (2007) Competition, transmission and bank pricing policies: Evidence from Belgian loan and deposit markets. Journal of Banking \& Finance 31(1):259-278. doi:10.1016/j.jbankfin.2006.03.003

De Haan L, Sterken E (2011) Bank-specific daily interest rate adjustment in the Dutch mortgage market. Journal of Financial Services Research 39(3):145-159. doi:10.1007/s10693-010-0095-2

Eberhardt M, Bond S (2009) Cross-section dependence in nonstationary panel models: a novel estimator. MPRA Working Paper No. 17692. University Library of Munich, Germany.

Eberhardt M, Presbitero AF (2015) Public debt and growth: Heterogeneity and non-linearity. Journal of International Economics 97(1):45-58. doi:10.1016/j.jinteco.2015.04.005

Eberhardt M, Teal F (2013) Structural change and cross-country growth empirics. World Bank Economic Review 27(2):229-271. doi:10.1093/wber/lhs020

ECB (2013) Articles assessing the retail bank interest rate pass-through in the euro area at times of financial fragmentation. ECB Monthly Bulletin August:75-91.

Égert B, Crespo-Cuaresma J, Reininger T (2007) Interest rate pass-through in Central and Eastern Europe: Reborn from ashes merely to pass away? Journal of Policy Modeling 29(2):209-225. doi:10.1016/j.jpolmod.2007.01.005

Fabbro D, Hack M (2011) The effects of funding costs and risk on banks' lending rates. RBA Monthly Bulletin March:35-42.

Fiszeder P, Pietryka I (2017) Monetary policy in steering the EONIA and POLONIA rates in the Eurosystem and Poland: a comparative analysis. Empirical Economics :87-100. doi:10.1007/s00181-017-1285-7

Freixas X, Rochet JC (2008) Microeconomics of Banking (2nd edn.). MIT Press, Cambridge.

Fuertes A, Heffernan S, Kalotychou E (2010) How do UK banks react to changing central bank rates? Journal of Financial Services Research 37(2):99-130. doi:10.1007/s10693009-0056-9

Guttmann R, Rodgers D (2015) International banking and liquidity risk transmission: Evidence from Australia. IMF Economic Review 63(3) 411-425. doi:10.1057/imfer.2015.27

Hannan TH, Berger AN (1991) The rigidity of prices: Evidence from the banking industry. The American Economic Review 81(4):938-945.

Horváth R, Podpiera A (2012) Heterogeneity in bank pricing policies: The Czech evidence. Economic Systems 36(1):87-108. doi:10.1016/j.ecosys.2011.03.002

Hristov N, Hülsewig O, Wollmershäuser T (2014) The interest rate pass-through in the Euro area during the global financial crisis. Journal of Banking \& Finance 48:104-119. doi:10.1016/j.jbankfin.2014.08.004

Illes A, Lombardi MJ, Mizen P (2015) Why did bank lending rates diverge from policy rates after the financial crisis? BIS Working Papers No. 486.

Imbs J, Mumtaz H, Ravn MO, Rey H (2005) PPP strikes back: Aggregation and the real exchange rate. The Quarterly Journal of Economics 120(1):1-43.

IMF (2017) Financial soundness indicators. International Monetary Funds. http://data.imf.org/?sk=51B096FA-2CD2-40C2-8D09-0699CC1764DA. Accessed 24 April 242017.

Jansen ES (2013) Wealth effects on consumption in financial crises: The case of Norway. Empirical Economics 45(2):873-904. doi:10.1007/s00181-012-0640-y

Kapetanios G, Pesaran MH, Yamagata T (2011) Panels with non-stationary multifactor error structures. Journal of Econometrics 160(2):326-348. doi:10.1016/j.jeconom.2010.10.001

Kopecky KJ, Van Hoose DD (2012) Imperfect competition in bank retail markets, deposit 
and loan rate dynamics, and incomplete pass through. Journal of Money, Credit and Banking 44(6):1185-1205. doi:10.1111/j.1538-4616.2012.00527.x

Lim GC, Tsiaplias S, Chua CL (2013) Bank and official interest rates: How do they interact over time? Economic Record, 89(285):160-174. doi:10.1111/1475-4932.12030

Liu MH, Margaritis D, Qiao Z (2016) The global financial crisis and retail interest rate passthrough in Australia. Review of Pacific Basin Financial Markets and Policies 19(4): [Abstract]. doi:10.1142/S0219091516500260

Liu MH, Margaritis D, Tourani-Rad A (2011) Asymmetric information and price competition in small business lending. Journal of Banking \& Finance 35(9):2189-2196. doi:10.1016/j.jbankfin.2011.01.022

Mark NC, Ogaki M, Sul D (2005) Seemingly unrelated cointegrating regressions. Review of Economic Studies 72(3):797-820.

Naraidoo R, Raputsoane L (2015) Financial markets and the response of monetary policy to uncertainty in South Africa. Empirical Economics 49(1):255-278. doi:10.1007/s00181014-0866-y

Omay T, Çorakcı A, Emirmahmutoglu F (2017) Real interest rates: nonlinearity and structural breaks. Empirical Economics 52(1):283-307. doi:10.1007/s00181-015-1065-1

Payne JE (2007) Interest rate pass through and asymmetries in adjustable rate mortgages. Applied Financial Economics 17(17):1369-1376. doi:10.1080/09603100601018872

Pesaran MH (2004) General diagnostic tests for cross section dependence in panels Cambridge Working Papers in Economics No. 435. CESifo Working Papers Series 1229. University of Cambridge.

Pesaran MH (2006) Estimation and inference in large heterogeneous panels with a multifactor error structure. Econometrica 74(4):967-1012. doi:10.1111/j.14680262.2006.00692.x

Pesaran MH (2007) A simple panel unit root test in the presence of cross-section dependence. Journal of Applied Econometrics 22(2):265-312. doi:10.1002/jae.951

Pesaran MH (2015) Testing weak cross-sectional dependence in large p anels. Econometric Reviews, 34(6-10):1089-1117. doi:10.1080/07474938.2014.956623

Pesaran MH, Vanessa Smith L, Yamagata T (2013) Panel unit root tests in the presence of a multifactor error structure. Journal of Econometrics 175(2):94-115. doi:10.1016/j.jeconom.2013.02.001

Pesaran MH, Yamagata T (2008) Testing slope homogeneity in large panels. Journal of Econometricsnomics 142:50-93. doi:10.1016/j.econlet.2007.05.010

Ralston D, Davis K (2011) The future of Australian bank funding. The Australian Center for Financial Studies (ACFS) and KPMG Research Report.

RBA (2006) Australian banks' global bond funding. RBA Monthly Bulletin August:1-6.

Reese S, Westerlund J (2016) Panicca: Panic on cross-section averages. Journal of Applied Econometrics 31(6):961-981. doi:10.1002/jae.2487

Robstad Ø (2018) House prices, credit and the effect of monetary policy in Norway: evidence from structural VAR models. Empirical Economics 54(2):461-483. doi:10.1007/s00181016-1222-1

Rousseas S (1985) A markup theory of bank loan rates. Journal of Post Keynesian Economics 8(1):135-144. doi:10.1080/01603477.1985.11489549

Sander H, Kleimeier S (2004) Convergence in euro-zone retail banking? What interest rate pass-through tells us about monetary policy transmission, competition and integration. Journal of International Money and Finance 23(3):461-492. doi:10.1016/j.jimonfin.2004.02.001

Sathye M (2013) Financial crisis and interest rate pass-through in Australia. Review of Pacific Basin Financial Markets and Policies 16(4):1-22. 
doi:10.1142/S0219091513500239

Shin Y, Yu B, Greenwood-Nimmo M (2014) Modelling asymmetric cointegration and dynamic multipliers in a nonlinear ARDL framework. In: Horrace W, Sickles R (eds) The Festschrift in Honor of Peter Schmidt.: Econometric Methods and Applications. Springer, New York, pp 281-314.

Sorensen C, Werner T (2006) Bank interest rate pass-through in the Euro area: a cross country comparison. ECB Working Paper Series No. 580.

Toolsema LA, Jacobs JPAM (2007) Why do prices rise faster than they fall? With an application to mortgage rates. Managerial and Decision Economics 28(7):701-712. doi: $10.1002 /$ mde. 1382

Turner G, Nugent J (2015) International linkages of the Australian banking system: Implications for financial stability. The Finsia Journal of Applied Finance (3):34-43.

Valadkhani A, Anwar S (2012) Interest rate pass-through and the asymmetric relationship between the cash rate and the mortgage rate. Economic Record 88(282):341-350. doi:10.1111/j.1475-4932.2012.00823.x

Westerlund J (2007) Testing for error correction in panel data. Oxford Bulletin of Economics and Statistics. doi:10.1111/j.1468-0084.2007.00477.x

Wilkins K, Gardner G, Chapman B (2016) Developments in banks ' funding costs and lending rates. RBA Monthly Bulletin March:21-30. 
Table 1 Symmetric results: full sample

\begin{tabular}{|c|c|c|c|c|c|c|c|c|}
\hline \multirow[t]{2}{*}{ Variable } & \multicolumn{2}{|c|}{ Sector } & \multicolumn{2}{|c|}{ Major } & \multicolumn{2}{|c|}{ Foreign } & \multicolumn{2}{|c|}{ Region } \\
\hline & [1] & [2] & [1] & [2] & [1] & [2] & [1] & [2] \\
\hline \multicolumn{9}{|c|}{ A. $E R-B B$} \\
\hline$E R(-1)$ & & $\begin{array}{l}0.458^{* * *} \\
(0.048)\end{array}$ & & $\begin{array}{l}0.506^{* * *} \\
(0.069)\end{array}$ & & $\begin{array}{l}0.503^{* * *} \\
(0.051)\end{array}$ & & $\begin{array}{l}0.426^{* * *} \\
(0.064)\end{array}$ \\
\hline \multirow[t]{2}{*}{$L_{B B}$} & $0.668^{* * *}$ & $0.362^{* * *}$ & $0.373^{* * *}$ & $0.800^{* * * *}$ & $0.266^{* * *}$ & $0.707^{* * * *}$ & $0.666^{* * *}$ & $0.375^{* * * *}$ \\
\hline & $(0.011)$ & $(0.026)$ & $(0.008)$ & $(0.004)$ & $(0.051)$ & $(0.026)$ & $(0.015)$ & $(0.037)$ \\
\hline \multirow[t]{2}{*}{$U C$} & $0.994^{* * *}$ & $0.966^{* * *}$ & $1.000^{* * *}$ & $1.000^{* * *}$ & $1.000^{* * *}$ & $1.000^{* * * *}$ & $0.991^{* * *}$ & $0.944^{* * *}$ \\
\hline & $(0.045)$ & $(0.051)$ & $(0.016)$ & $(0.017)$ & $(0.057)$ & $(0.056)$ & $(0.062)$ & $(0.076)$ \\
\hline \multirow[t]{2}{*}{ Constant } & $3.218^{* * *}$ & $4.829^{* * *}$ & $4.759^{* * *}$ & $3.743^{* * *}$ & $5.326^{* * *}$ & $4.277^{* * *}$ & $3.208^{* * *}$ & $4.759^{* * *}$ \\
\hline & $(0.072)$ & $(0.123)$ & $(0.049)$ & $(0.048)$ & $(0.281)$ & $(0.224)$ & (0.099) & $(0.167)$ \\
\hline $\mathrm{I}(\cdot) \hat{\mathrm{e}}_{\mathrm{it}}$ & $-19.099^{a}$ & $-17.045^{a}$ & $-6.190^{a}$ & $-5.505^{a}$ & $-5.881^{\mathrm{a}}$ & $-2.884^{\mathrm{a}}$ & $-14.342^{\mathrm{a}}$ & $-11.722^{a}$ \\
\hline RMSE & 0.124 & 0.125 & 0.056 & 0.048 & 0.075 & 0.072 & 0.141 & 0.146 \\
\hline Obs. & 13,815 & 13,795 & 2,824 & 2,820 & 2,118 & 2,115 & 8,873 & 8,860 \\
\hline Banks & 20 & 20 & 4 & 4 & 3 & 3 & 13 & 13 \\
\hline \multicolumn{9}{|c|}{ B. ER-CR } \\
\hline \multirow[t]{2}{*}{$E R(-1)$} & & $0.462^{* * *}$ & & $0.508^{* * *}$ & & $0.498^{* * *}$ & & $0.437^{* * *}$ \\
\hline & & $(0.041)$ & & $(0.065)$ & & $(0.024)$ & & $(0.053)$ \\
\hline \multirow[t]{2}{*}{$L_{C R}$} & $0.654^{* * *}$ & $0.332^{* * *}$ & $0.372^{* * *}$ & $0.758^{* * *}$ & $0.265^{* * *}$ & $0.701^{* * *}$ & $0.651^{* * *}$ & $0.350^{* * *}$ \\
\hline & $(0.013)$ & $(0.033)$ & $(0.009)$ & $(0.004)$ & $(0.055)$ & $(0.030)$ & $(0.017)$ & $(0.048)$ \\
\hline \multirow[t]{2}{*}{$U C$} & $0.994^{* * *}$ & $0.956^{* * *}$ & $1.000^{* * *}$ & $1.001^{* * *}$ & $1.000^{* * *}$ & $1.000^{* * *}$ & $0.991^{* * *}$ & $0.926^{* * *}$ \\
\hline & $(0.043)$ & $(0.056)$ & $(0.017)$ & $(0.018)$ & $(0.057)$ & $(0.057)$ & $(0.059)$ & $(0.084)$ \\
\hline \multirow[t]{2}{*}{ Constant } & $3.527^{* * * *}$ & $5.081^{* * * *}$ & $4.904^{* * * *}$ & $4.133^{* * *}$ & $5.429^{* * * *}$ & $4.558^{* * * *}$ & $3.521^{* * * *}$ & $4.849^{* * * *}$ \\
\hline & $(0.077)$ & $(0.148)$ & $(0.051)$ & $(0.048)$ & $(0.291)$ & $(0.241)$ & $(0.103)$ & $(0.196)$ \\
\hline $\mathrm{I}(\cdot) \hat{\mathrm{e}}_{i t}$ & $-18.352^{\mathrm{a}}$ & $-17.196^{a}$ & $-6.190^{a}$ & $-5.434^{a}$ & $-6.007^{a}$ & $-2.088^{a}$ & $-13.348^{a}$ & $-11.724^{a}$ \\
\hline RMSE & 0.120 & 0.125 & 0.055 & 0.048 & 0.074 & 0.070 & 0.137 & 0.147 \\
\hline Obs. & 13,815 & 13,795 & 2,824 & 2,820 & 2,118 & 2,115 & 8,873 & 8,860 \\
\hline Banks & 20 & 20 & 4 & 4 & 3 & 3 & 13 & 13 \\
\hline
\end{tabular}

(i) Table 1 reports the symmetric results for the full sample $T=706$ weeks estimated by the linear AMG models with the effective mortgage rates as dependent variables $E R$. The mean coefficients across banks in the static and dynamic models are reported in [1] and [2] respectively for each bank group. Standard errors are in parentheses. Superscripts ${ }^{*},{ }^{* *}$, and ${ }^{* * *}$ indicate 10,5 , and $1 \%$ levels of the significance. (ii) Panel A reports the results of the mortgage rate and foreign-funds rate, while panel $\mathrm{B}$ exhibits those of the mortgage rate and cash rate nexus. (iii) $E R(-1)$ refers to the lagged-one coefficient of $E R$. $L_{B B}$ and $L_{C R}$ are the long-term coefficients of the foreign-funds rate and cash rate, respectively. $U C$ is the common process coefficient. (iv) Diagnostics tests on residuals include: a) I(') ê $\hat{i}_{i t}$ reports the Pesaran (2007) CIPS test with 2 lags, null of nonstationary, and asterisks ${ }^{\mathrm{a}}$ and ${ }^{\mathrm{b}}$ denote the rejection of the null hypothesis at the $1 \%$ level of significance on level and at $1 \mathrm{st}$ difference; b) Root mean square error (RMSE) indicates the residual size of each model. 
Table 2 Dynamic symmetric results: sub-samples

\begin{tabular}{|c|c|c|c|c|c|c|c|c|c|c|c|c|}
\hline \multirow[b]{2}{*}{ Variable } & \multicolumn{3}{|c|}{ Sector } & \multicolumn{3}{|c|}{ Major } & \multicolumn{3}{|c|}{ Foreign } & \multicolumn{3}{|c|}{ Region } \\
\hline & $\begin{array}{l}\text { PreGFC } \\
(T=261) \\
\end{array}$ & $\begin{array}{l}\text { GFC } \\
(T=131)\end{array}$ & $\begin{array}{l}\text { PostGFC } \\
(T=314) \\
\end{array}$ & $\begin{array}{l}\text { PreGFC } \\
(T=261) \\
\end{array}$ & $\begin{array}{l}\text { GFC } \\
(T=131)\end{array}$ & $\begin{array}{l}\text { PostGFC } \\
(T=314)\end{array}$ & $\begin{array}{l}\text { PreGFC } \\
(T=261) \\
\end{array}$ & $\begin{array}{l}\text { GFC } \\
(T=131)\end{array}$ & $\begin{array}{l}\text { PostGFC } \\
(T=314)\end{array}$ & $\begin{array}{l}\text { PreGFC } \\
(T=261) \\
\end{array}$ & $\begin{array}{l}\text { GFC } \\
(T=131)\end{array}$ & $\begin{array}{l}\text { PostGFC } \\
(T=314)\end{array}$ \\
\hline \multicolumn{13}{|c|}{$\mathrm{A}: \mathrm{ER}-\mathrm{BB}$} \\
\hline$E R(-1)$ & $\begin{array}{l}0.462^{* * *} \\
(0.044)\end{array}$ & $\begin{array}{l}0.492^{* * *} \\
(0.0325)\end{array}$ & $\begin{array}{l}0.505^{* * *} \\
(0.020)\end{array}$ & $\begin{array}{l}0.515^{* * *} \\
(0.073)\end{array}$ & $\begin{array}{l}0.510^{* * *} \\
(0.075)\end{array}$ & $\begin{array}{l}0.507^{* * *} \\
(0.033)\end{array}$ & $\begin{array}{l}0.407^{* *} \\
(0.198)\end{array}$ & $\begin{array}{l}0.500^{* * *} \\
(0.012)\end{array}$ & $\begin{array}{l}0.506^{* * *} \\
(0.033)\end{array}$ & $\begin{array}{l}0.453^{* * *} \\
(0.057)\end{array}$ & $\begin{array}{l}0.485^{* * *} \\
(0.040)\end{array}$ & $\begin{array}{l}0.504^{* * *} \\
(0.025)\end{array}$ \\
\hline$L_{B B}$ & $\begin{array}{l}1.064^{* * *} \\
(0.026)\end{array}$ & $\begin{array}{l}0.478^{* * *} \\
(0.0113)\end{array}$ & $\begin{array}{l}0.164^{* *} \\
(0.072)\end{array}$ & $\begin{array}{l}1.077^{* * *} \\
(0.022)\end{array}$ & $\begin{array}{l}0.652^{* * *} \\
(0.011)\end{array}$ & $\begin{array}{l}0.822^{* * *} \\
(0.012)\end{array}$ & $\begin{array}{l}1.025^{* * *} \\
(0.022)\end{array}$ & $\begin{array}{l}0.763^{* * *} \\
(0.035)\end{array}$ & $\begin{array}{l}0.714^{* * *} \\
(0.006)\end{array}$ & $\begin{array}{l}1.068^{* * *} \\
(0.039)\end{array}$ & $\begin{array}{l}0.479^{* * *} \\
(0.013)\end{array}$ & $\begin{array}{l}0.196^{*} \\
(0.108)\end{array}$ \\
\hline$U C$ & $\begin{array}{l}1.001^{* * *} \\
(0.095)\end{array}$ & $\begin{array}{l}1.001^{* * *} \\
(0.024)\end{array}$ & $\begin{array}{l}1.000^{* * *} \\
(0.063)\end{array}$ & $\begin{array}{l}1.002^{* * *} \\
(0.038)\end{array}$ & $\begin{array}{l}1.002^{* * *} \\
(0.025)\end{array}$ & $\begin{array}{l}1.001^{* * *} \\
(0.016)\end{array}$ & $\begin{array}{l}1.001^{* * * *} \\
(0.212)\end{array}$ & $\begin{array}{l}1.000^{* * *} \\
(0.062)\end{array}$ & $\begin{array}{l}1.001^{* * *} \\
(0.031)\end{array}$ & $\begin{array}{l}1.000^{* * *} \\
(0.137)\end{array}$ & $\begin{array}{l}0.999^{* * *} \\
(0.029)\end{array}$ & $\begin{array}{l}1.000^{* * *} \\
(0.098)\end{array}$ \\
\hline Constant & $\begin{array}{l}1.278^{* * *} \\
(0.165)\end{array}$ & $\begin{array}{l}5.037^{* * * *} \\
(0.0801)\end{array}$ & $\begin{array}{l}5.952^{* * *} \\
(0.375)\end{array}$ & $\begin{array}{l}1.231^{* * *} \\
(0.155)\end{array}$ & $\begin{array}{l}3.969^{* * *} \\
(0.075)\end{array}$ & $\begin{array}{l}3.692^{* * * *} \\
(0.048)\end{array}$ & $\begin{array}{l}1.514^{* * * *} \\
(0.144)\end{array}$ & $\begin{array}{l}3.846^{* * *} \\
(0.244)\end{array}$ & $\begin{array}{l}4.261^{* * * *} \\
(0.171)\end{array}$ & $\begin{array}{l}1.238^{* * *} \\
(0.247)\end{array}$ & $\begin{array}{l}4.672^{* * *} \\
(0.082)\end{array}$ & $\begin{array}{l}5.747^{* * * *} \\
(0.552)\end{array}$ \\
\hline $\mathrm{I}(\cdot) \hat{\mathrm{e}}_{\mathrm{it}}$ & $-3.145^{\mathrm{a}}$ & $-3.848^{a}$ & $-4.443^{a}$ & $-3.646^{a}$ & $-4.439^{a}$ & $-3.903^{a}$ & $-0.173^{b}$ & $-2.274^{b}$ & $-3.040^{a}$ & $-3.551^{a}$ & $-3.749^{a}$ & $-4.183^{a}$ \\
\hline RMSE & 0.077 & 0.090 & 0.079 & 0.015 & 0.057 & 0.041 & 0.069 & 0.078 & 0.035 & 0.084 & 0.090 & 0.088 \\
\hline Obs. & 5,200 & 2,620 & 5,652 & 1,040 & 524 & 1,256 & 780 & 393 & 942 & 3,380 & 1,703 & 3,756 \\
\hline Banks & 20 & 20 & 18 & 4 & 4 & 4 & 3 & 3 & 3 & 13 & 13 & 12 \\
\hline \multicolumn{13}{|c|}{$\mathrm{B}: \mathrm{ER}-\mathrm{CR}$} \\
\hline \multirow[t]{2}{*}{$E R(-1)$} & $0.387^{* * *}$ & $0.484^{* * *}$ & $0.508^{* * *}$ & $0.391^{* * *}$ & $0.506^{* * *}$ & $0.506^{* * *}$ & $0.467^{*}$ & $0.495^{* * *}$ & $0.509^{* * *}$ & $0.382^{* * *}$ & $0.481^{* * *}$ & $0.509^{* * *}$ \\
\hline & $(0.043)$ & $(0.034)$ & $(0.021)$ & $(0.095)$ & $(0.061)$ & $(0.033)$ & $(0.283)$ & $(0.028)$ & $(0.042)$ & $(0.043)$ & $(0.041)$ & $(0.026)$ \\
\hline \multirow[t]{2}{*}{$L_{C R}$} & $0.972^{* * * *}$ & $0.371^{* * *}$ & 0.164 & $0.984^{* * *}$ & $0.898^{* * *}$ & $0.772^{* * *}$ & $0.934^{* * *}$ & $0.877^{* * *}$ & $0.701^{* * * *}$ & $0.976^{* * *}$ & $0.373^{* * *}$ & 0.228 \\
\hline & $(0.0406)$ & $(0.0199)$ & $(0.140)$ & $(0.018)$ & $(0.012)$ & $(0.014)$ & $(0.062)$ & $(0.038)$ & $(0.008)$ & $(0.060)$ & $(0.025)$ & $(0.209)$ \\
\hline \multirow[t]{2}{*}{$U C$} & $0.979^{* * *}$ & $0.999^{* * *}$ & $0.996^{* * *}$ & $0.900^{* * *}$ & $1.008^{* * *}$ & $1.001^{* * * *}$ & 1.028 & $1.000^{* * *}$ & $1.001^{* * * *}$ & $0.977^{* * *}$ & $0.993^{* * *}$ & $0.995^{* * *}$ \\
\hline & $(0.236)$ & $(0.035)$ & $(0.063)$ & $(0.241)$ & $(0.025)$ & $(0.040)$ & $(0.659)$ & $(0.068)$ & $(0.050)$ & $(0.342)$ & $(0.043)$ & $(0.095)$ \\
\hline \multirow[t]{2}{*}{ Constant } & $2.033^{* * *}$ & $5.790^{* * * *}$ & $6.963^{* * *}$ & $1.998^{* * *}$ & $3.149^{* * *}$ & $4.104^{* * *}$ & $2.256^{* * *}$ & $3.372^{* * * *}$ & $4.559^{* * *}$ & $1.998^{* * *}$ & $5.771^{* * *}$ & $5.530^{* * * *}$ \\
\hline & $(0.246)$ & $(0.122)$ & $(0.778)$ & $(0.124)$ & $(0.074)$ & $(0.050)$ & $(0.419)$ & $(0.246)$ & $(0.176)$ & $(0.362)$ & $(0.148)$ & $(1.062)$ \\
\hline $\mathrm{I}(\cdot) \hat{\mathrm{e}}_{\mathrm{it}}$ & $-2.851^{a}$ & $-3.876^{a}$ & $-4.324^{\mathrm{a}}$ & $-3.974^{a}$ & $-3.618^{a}$ & $-5.361^{\mathrm{a}}$ & $-5.388^{a}$ & $-3.582^{a}$ & $-3.516^{\mathrm{a}}$ & $-2.220^{\mathrm{a}}$ & $-3.859^{a}$ & $-4.085^{a}$ \\
\hline RMSE & 0.083 & 0.089 & 0.079 & 0.013 & 0.059 & 0.041 & 0.047 & 0.078 & 0.039 & 0.090 & 0.089 & 0.088 \\
\hline Obs. & 5,200 & 2,620 & 5,652 & 1,040 & 524 & 1,256 & 780 & 393 & 942 & 3,380 & 1,703 & 3,756 \\
\hline Banks & 20 & 20 & 18 & 4 & 4 & 4 & 3 & 3 & 3 & 13 & 13 & 12 \\
\hline
\end{tabular}

(i) Table 2 reports the dynamic symmetric AMG results of sub-samples for each bank group in successive columns. (ii) The remainders are similar to Table 1. 
Table 3 Asymmetric results: full sample

\begin{tabular}{|c|c|c|c|c|c|c|c|c|}
\hline \multirow[t]{2}{*}{ Variable } & \multicolumn{2}{|c|}{ Sector } & \multicolumn{2}{|c|}{ Major } & \multicolumn{2}{|c|}{ Foreign } & \multicolumn{2}{|c|}{ Region } \\
\hline & {$[1]$} & {$[2]$} & {$[1]$} & [2] & {$[1]$} & [2] & [1] & [2] \\
\hline \multicolumn{9}{|c|}{ A. $\mathrm{ER}-\mathrm{BB}$} \\
\hline$E R(-1)$ & & $\begin{array}{l}0.496^{* * *} \\
(0.032)\end{array}$ & & $\begin{array}{l}0.508^{* * *} \\
(0.063)\end{array}$ & & $\begin{array}{l}0.499^{* * *} \\
(0.022)\end{array}$ & & $\begin{array}{l}0.488^{* * *} \\
(0.043)\end{array}$ \\
\hline$L_{B B}^{+}$ & $\begin{array}{l}0.977^{* * *} \\
(0.018)\end{array}$ & $\begin{array}{l}0.737^{* * *} \\
(0.014)\end{array}$ & $\begin{array}{l}0.994^{* * *} \\
(0.005)\end{array}$ & $\begin{array}{l}1.007^{* * *} \\
(0.005)\end{array}$ & $\begin{array}{l}0.984^{* * *} \\
(0.010)\end{array}$ & $\begin{array}{l}0.954^{* * *} \\
(0.010)\end{array}$ & $\begin{array}{l}0.890^{* * *} \\
(0.025)\end{array}$ & $\begin{array}{l}0.775^{* * *} \\
(0.023)\end{array}$ \\
\hline$L_{B B}^{-}$ & $\begin{array}{l}0.883^{* * * *} \\
(0.020)\end{array}$ & $\begin{array}{l}0.681^{* * * *} \\
(0.015)\end{array}$ & $\begin{array}{l}0.906^{* * *} \\
(0.004)\end{array}$ & $\begin{array}{l}0.921^{* * *} \\
(0.004)\end{array}$ & $\begin{array}{l}0.882^{* * *} \\
(0.018)\end{array}$ & $\begin{array}{l}0.859^{* * *} \\
(0.018)\end{array}$ & $\begin{array}{l}0.808^{* * * *} \\
(0.027)\end{array}$ & $\begin{array}{l}0.712^{* * * *} \\
(0.025)\end{array}$ \\
\hline$U C$ & $\begin{array}{l}1.000^{* * *} \\
(0.042)\end{array}$ & $\begin{array}{l}1.001^{* * *} \\
(0.040)\end{array}$ & $\begin{array}{l}1.000^{* * *} \\
(0.015)\end{array}$ & $\begin{array}{l}1.001^{* * *} \\
(0.017)\end{array}$ & $\begin{array}{l}1.000^{* * *} \\
(0.045)\end{array}$ & $\begin{array}{l}1.000^{* * *} \\
(0.046)\end{array}$ & $\begin{array}{l}0.999^{* * *} \\
(0.050)\end{array}$ & $\begin{array}{l}0.999^{* * *} \\
(0.049)\end{array}$ \\
\hline Constant & $\begin{array}{l}6.567^{* * *} \\
(0.041)\end{array}$ & $\begin{array}{l}6.642^{* * *} \\
(0.041)\end{array}$ & $\begin{array}{l}6.599^{* * *} \\
(0.038)\end{array}$ & $\begin{array}{l}6.659^{* * *} \\
(0.039)\end{array}$ & $\begin{array}{l}6.619^{* * * *} \\
(0.066)\end{array}$ & $\begin{array}{l}6.679^{* * *} \\
(0.069)\end{array}$ & $\begin{array}{l}6.550^{* * *} \\
(0.061)\end{array}$ & $\begin{array}{l}6.625^{* * * *} \\
(0.062)\end{array}$ \\
\hline \multirow[t]{2}{*}{$W$-stat. } & 394.59 & 98.670 & 1742.60 & 1631.55 & 175.92 & 147.72 & 134.84 & 63.490 \\
\hline & {$[0.000]$} & {$[0.000]$} & {$[0.000]$} & {$[0.000]$} & {$[0.000]$} & {$[0.000]$} & {$[0.000]$} & {$[0.000]$} \\
\hline $\mathrm{I}(\cdot) \hat{\mathrm{e}}_{\mathrm{it}}$ & $-19.145^{\mathrm{a}}$ & $-15.601^{a}$ & $-6.190^{\mathrm{a}}$ & $-5.617^{\mathrm{a}}$ & $-6.032^{a}$ & $-4.079^{a}$ & $-14.332^{\mathrm{a}}$ & $-11.109^{a}$ \\
\hline RMSE & 0.149 & 0.144 & 0.055 & 0.047 & 0.071 & 0.067 & 0.176 & 0.172 \\
\hline Obs. & 13,815 & 13,795 & 2,824 & 2,820 & 2,118 & 2,115 & 8,873 & 8,860 \\
\hline Banks & 20 & 20 & 4 & 4 & 3 & 3 & 13 & 13 \\
\hline \multicolumn{9}{|c|}{ B. ER-CR } \\
\hline$E R(-1)$ & & $\begin{array}{l}0.480^{* * *} \\
(0.036)\end{array}$ & & $\begin{array}{l}0.488^{* * *} \\
(0.0256)\end{array}$ & & $\begin{array}{l}0.493^{* * *} \\
(0.036)\end{array}$ & & $\begin{array}{l}0.482^{* * *} \\
(0.053)\end{array}$ \\
\hline$L_{C R}^{+}$ & $\begin{array}{l}1.191^{* * *} \\
(0.017)\end{array}$ & $\begin{array}{l}1.194^{* * *} \\
(0.017)\end{array}$ & $\begin{array}{l}1.191^{* * *} \\
(0.006)\end{array}$ & $\begin{array}{l}1.191^{* * *} \\
(0.006)\end{array}$ & $\begin{array}{l}1.191^{* * *} \\
(0.002)\end{array}$ & $\begin{array}{l}1.191^{* * *} \\
(0.002)\end{array}$ & $\begin{array}{l}1.194^{* * *} \\
(0.023)\end{array}$ & $\begin{array}{l}1.185^{* * *} \\
(0.024)\end{array}$ \\
\hline$L_{C R}^{-}$ & $\begin{array}{l}0.846^{* * *} \\
(0.019)\end{array}$ & $\begin{array}{l}0.850^{* * *} \\
(0.019)\end{array}$ & $\begin{array}{l}0.869^{* * *} \\
(0.005)\end{array}$ & $\begin{array}{l}0.869^{* * *} \\
(0.005)\end{array}$ & $\begin{array}{l}0.828^{* * *} \\
(0.025)\end{array}$ & $\begin{array}{l}0.828^{* * *} \\
(0.025)\end{array}$ & $\begin{array}{l}0.846^{* * *} \\
(0.027)\end{array}$ & $\begin{array}{l}0.843^{* * *} \\
(0.028)\end{array}$ \\
\hline$U C$ & $\begin{array}{l}0.998^{* * *} \\
(0.058)\end{array}$ & $\begin{array}{l}1.001^{* * *} \\
(0.050)\end{array}$ & $\begin{array}{l}1.000^{* * *} \\
(0.091)\end{array}$ & $\begin{array}{l}0.999^{* * *} \\
(0.055)\end{array}$ & $\begin{array}{l}1.000^{* * *} \\
(0.101)\end{array}$ & $\begin{array}{l}0.999^{* * *} \\
(0.096)\end{array}$ & $\begin{array}{l}0.995^{* * *} \\
(0.091)\end{array}$ & $\begin{array}{l}0.999^{* * *} \\
(0.082)\end{array}$ \\
\hline Constant & $\begin{array}{l}6.605^{* * *} \\
(0.044)\end{array}$ & $\begin{array}{l}6.618^{* * *} \\
(0.044)\end{array}$ & $\begin{array}{l}6.639^{* * *} \\
(0.043)\end{array}$ & $\begin{array}{l}6.639^{* * *} \\
(0.041)\end{array}$ & $\begin{array}{l}6.659^{* * *} \\
(0.080)\end{array}$ & $\begin{array}{l}6.659^{* * *} \\
(0.079)\end{array}$ & $\begin{array}{l}6.582^{* * *} \\
(0.065)\end{array}$ & $\begin{array}{l}6.601^{* * *} \\
(0.066)\end{array}$ \\
\hline$W$-stat. & $\begin{array}{l}655.82 \\
{[0.000]}\end{array}$ & $\begin{array}{l}671.92 \\
{[0.000]}\end{array}$ & $\begin{array}{l}3267.96 \\
{[0.000]}\end{array}$ & $\begin{array}{l}2918.85 \\
{[0.000]}\end{array}$ & $\begin{array}{l}232.34 \\
{[0.000]}\end{array}$ & $\begin{array}{l}232.85 \\
{[0.000]}\end{array}$ & $\begin{array}{l}315.11 \\
{[0.000]}\end{array}$ & $\begin{array}{l}321.58 \\
{[0.000]}\end{array}$ \\
\hline $\mathrm{I}\left({ }^{\prime}\right) \hat{\mathrm{e}}_{\mathrm{it}}$ & $-18.608^{a}$ & $-15.812^{a}$ & $-6.190^{a}$ & $-5.293^{a}$ & $-6.134^{\mathrm{a}}$ & $-2.163^{b}$ & $-13.961^{a}$ & $-11.921^{\mathrm{a}}$ \\
\hline RMSE & 0.151 & 0.147 & 0.052 & 0.046 & 0.068 & 0.064 & 0.176 & 0.173 \\
\hline Obs. & 13,815 & 13,795 & 2,824 & 2,820 & 2,118 & 2,115 & 8,873 & 8,860 \\
\hline Banks & 20 & 20 & 4 & 4 & 3 & 3 & 13 & 13 \\
\hline
\end{tabular}

(i) Table 3 reports the asymmetric results for the full sample. The mean coefficients across banks in the static and dynamic models are reported in [1] and [2] respectively for each bank group. (ii) $E R(-1)$ is the lagged-one coefficient of $E R$. $L_{X i t}^{+}$and $\bar{L}_{X i t}^{-}$refer to asymmetric coefficients of the cost-of-fund rates corresponding to increases and decreases in $B B$ or $C R$, respectively. $U C$ is the common process coefficient. (iii) Standard errors are in parentheses, while $p$-values are in square brackets. Superscripts ${ }^{*},{ }^{* *}$, and ${ }^{* * *}$ indicate 10,5 , and $1 \%$ levels of the significance. (iv) $W$-stat. is the results of the Wald test for the equality of long-term up and down effects.

(v) Diagnostics tests on residuals include: a) I(') $\hat{e}_{i t}$ reports the Pesaran (2007) CIPS test with 2 lags, null of nonstationary. Asterisks ${ }^{\mathrm{a}}$ and ${ }^{\mathrm{b}}$ denote the rejection of the null hypothesis at the $1 \%$ level of significance on level and at 1st difference; b) Root mean square error (RMSE) indicates the residual size of each model. 
Table 4 Dynamic asymmetric results: sub-samples

\begin{tabular}{|c|c|c|c|c|c|c|c|c|c|c|c|c|}
\hline \multirow{2}{*}{ Variable } & \multicolumn{3}{|c|}{ Sector } & \multicolumn{3}{|c|}{ Major } & \multicolumn{3}{|c|}{ Foreign } & \multicolumn{3}{|c|}{ Region } \\
\hline & PreGFC & GFC & PostGFC & PreGFC & GFC & PostGFC & PreGFC & GFC & PostGFC & PreGFC & GFC & PostGFC \\
\hline \multicolumn{13}{|c|}{$\mathrm{A}: \mathrm{ER}-\mathrm{BB}$} \\
\hline \multirow[t]{2}{*}{$E R(-1)$} & $0.464^{* * *}$ & $0.502^{* * *}$ & $0.506^{* * *}$ & $0.514^{* * *}$ & $0.510^{* * *}$ & $0.507^{* * *}$ & $0.451^{* *}$ & $0.499^{* * *}$ & $0.501^{* * *}$ & $0.449^{* * *}$ & $0.501^{* * *}$ & $0.509^{* * *}$ \\
\hline & $(0.040)$ & $(0.028)$ & $(0.019)$ & $(0.072)$ & $(0.075)$ & $(0.029)$ & $(0.193)$ & $(0.024)$ & $(0.015)$ & $(0.048)$ & $(0.035)$ & $(0.025)$ \\
\hline \multirow[t]{2}{*}{$L_{B B}^{+}$} & $0.334^{* * *}$ & $0.995^{* * *}$ & $1.005^{* * *}$ & $0.337^{* * * *}$ & $1.011^{* * * *}$ & $1.127^{* * * *}$ & $0.321^{* * *}$ & $1.054^{* * *}$ & $1.119^{* * * *}$ & $0.336^{* * *}$ & $1.021^{* * *}$ & $0.967^{* * *}$ \\
\hline & $(0.070)$ & $(0.013)$ & $(0.060)$ & $(0.009)$ & $(0.010)$ & $(0.007)$ & $(0.071)$ & $(0.044)$ & $(0.036)$ & $(0.098)$ & $(0.018)$ & $(0.088)$ \\
\hline \multirow[t]{2}{*}{$L_{B B}^{-}$} & 0.0008 & $0.860^{* * *}$ & $0.901^{* * *}$ & -0.0017 & $0.843^{* * *}$ & $1.008^{* * *}$ & 0.0004 & $0.915^{* * *}$ & $0.980^{* * *}$ & 0.00183 & $0.742^{* * * *}$ & $0.877^{* * *}$ \\
\hline & $(0.079)$ & $(0.007)$ & $(0.057)$ & $(0.023)$ & $(0.010)$ & $(0.005)$ & $(0.073)$ & $(0.038)$ & $(0.018)$ & $(0.107)$ & $(0.006)$ & $(0.086)$ \\
\hline \multirow[t]{2}{*}{$U C$} & $1.002^{* * *}$ & $1.003^{* * *}$ & $1.001^{* * *}$ & $1.003^{* * *}$ & $1.002^{* * *}$ & $1.001^{* * *}$ & $1.005^{* * *}$ & $1.000^{* * *}$ & $1.000^{* * *}$ & $1.000^{* * *}$ & $1.002^{* * *}$ & $1.001^{* * *}$ \\
\hline & $(0.146)$ & $(0.021)$ & $(0.080)$ & $(0.030)$ & $(0.029)$ & $(0.006)$ & $(0.276)$ & $(0.056)$ & $(0.046)$ & $(0.210)$ & $(0.024)$ & $(0.122)$ \\
\hline \multirow[t]{2}{*}{ Constant } & $6.621^{* * * *}$ & $6.321^{* * * *}$ & $6.467^{* * *}$ & $6.641^{* * * *}$ & $6.233^{* * *}$ & $6.346^{* * *}$ & $6.664^{* * *}$ & $6.214^{* * *}$ & $6.271^{* * *}$ & $6.605^{* * *}$ & $5.831^{* * * *}$ & $6.616^{* * *}$ \\
\hline & $(0.072)$ & $(0.062)$ & $(0.100)$ & $(0.052)$ & $(0.028)$ & $(0.142)$ & $(0.142)$ & $(0.087)$ & $(0.120)$ & $(0.108)$ & $(0.100)$ & $(0.139)$ \\
\hline \multirow[t]{2}{*}{$W$-stat. } & 660.50 & 228.04 & 93.010 & 535.44 & 12583.5 & 166.60 & 686.08 & 77.350 & 25.840 & 766.65 & 329.29 & 55.760 \\
\hline & {$[0.000]$} & {$[0.000]$} & {$[0.000]$} & {$[0.000]$} & {$[0.000]$} & {$[0.000]$} & {$[0.000]$} & {$[0.000]$} & {$[0.000]$} & {$[0.000]$} & {$[0.000]$} & {$[0.000]$} \\
\hline $\mathrm{I}(\cdot) \hat{e}_{\mathrm{it}}$ & $-3.741^{\mathrm{a}}$ & $-3.817^{\mathrm{a}}$ & $-4.171^{a}$ & $-3.678^{a}$ & $-4.533^{a}$ & $-4.160^{a}$ & $-1.876^{\mathrm{b}}$ & $-2.829^{a}$ & $-3.165^{\mathrm{a}}$ & $-3.906^{a}$ & $-3.416^{\mathrm{a}}$ & $-3.997^{\mathrm{a}}$ \\
\hline RMSE & 0.056 & 0.099 & 0.071 & 0.015 & 0.057 & 0.040 & 0.057 & 0.076 & 0.029 & 0.056 & 0.103 & 0.080 \\
\hline \multicolumn{13}{|c|}{ B: ER-CR } \\
\hline \multirow[t]{2}{*}{$E R(-1)$} & $0.387^{* * *}$ & $0.484^{* * *}$ & $0.502^{* * *}$ & $0.388^{* * *}$ & $0.473^{* * *}$ & $0.504^{* * *}$ & $0.468^{*}$ & $0.497^{* * *}$ & $0.502^{* * *}$ & $0.382^{* * *}$ & $0.500^{* * *}$ & $0.506^{* * *}$ \\
\hline & $(0.043)$ & $(0.032)$ & $(0.019)$ & (0.099) & $(0.018)$ & $(0.024)$ & $(0.280)$ & $(0.039)$ & $(0.014)$ & $(0.043)$ & $(0.038)$ & $(0.027)$ \\
\hline \multirow[t]{2}{*}{$L_{C R}^{+}$} & $0.972^{* * *}$ & $1.526^{* * *}$ & -0.0025 & $0.984^{* * *}$ & $1.508^{* * *}$ & -0.002 & $0.934^{* * *}$ & $1.637^{* * *}$ & -0.0007 & $0.976^{* * *}$ & $1.496^{* * *}$ & -0.0024 \\
\hline & $(0.041)$ & $(0.028)$ & $(0.079)$ & $(0.018)$ & $(0.008)$ & $(0.0462)$ & $(0.062)$ & $(0.075)$ & $(0.127)$ & $(0.059)$ & $(0.040)$ & $(0.105)$ \\
\hline \multirow[t]{2}{*}{$L_{C R}^{-}$} & ND & $0.896^{\text {**** }}$ & $0.352^{* * *}$ & ND & $0.895^{* * *}$ & $0.386^{\text {*** }}$ & ND & $0.962^{* * *}$ & $0.323^{* * *}$ & ND & $0.931^{* * * *}$ & $0.352^{* * *}$ \\
\hline & & $(0.007)$ & $(0.027)$ & & $(0.011)$ & $(0.019)$ & & $(0.041)$ & $(0.021)$ & & $(0.007)$ & $(0.040)$ \\
\hline$U C$ & $\begin{array}{l}0.9 / 9 \\
(0.240)\end{array}$ & $\begin{array}{l}1.005 \\
(0.038)\end{array}$ & $\begin{array}{l}1.002 \\
(0.089)\end{array}$ & $\begin{array}{l}0.895 \\
(0.249)\end{array}$ & $\begin{array}{l}0.991 \\
(0.085)\end{array}$ & $\begin{array}{l}1.001 \\
(0.026)\end{array}$ & $\begin{array}{l}1.028 \\
(0.664)\end{array}$ & $\begin{array}{l}1.001 \\
(0.061)\end{array}$ & $\begin{array}{l}1.001 \\
(0.055)\end{array}$ & $\begin{array}{l}0.91 / \\
(0.347)\end{array}$ & $\begin{array}{l}1.010 \\
(0.031)\end{array}$ & $\begin{array}{l}1.002 \\
(0.134)\end{array}$ \\
\hline \multirow[t]{2}{*}{ Constant } & $6.623^{* * * *}$ & $5.777^{* * *}$ & $8.265^{* * *}$ & $6.644^{* * * *}$ & $5.842^{* * *}$ & $8.355^{* * *}$ & $6.668^{* * *}$ & $5.594^{* * *}$ & $8.226^{* * *}$ & $6.608^{* * *}$ & $5.815^{* * *}$ & $8.251^{* * *}$ \\
\hline & $(0.058)$ & $(0.061)$ & $(0.239)$ & $(0.044)$ & $(0.028)$ & $(0.201)$ & $(0.129)$ & $(0.104)$ & $(0.266)$ & $(0.087)$ & $(0.092)$ & $(0.334)$ \\
\hline \multirow[t]{2}{*}{$W$-stat. } & - & 484.34 & 101.01 & - & 13153.1 & 76.83 & - & 144.52 & 46.390 & - & 194.93 & 10.370 \\
\hline & & {$[0.000]$} & {$[0.000]$} & & {$[0.000]$} & {$[0.000]$} & & {$[0.000]$} & {$[0.000]$} & & {$[0.000]$} & {$[0.001]$} \\
\hline
\end{tabular}




\begin{tabular}{lllllllllllll}
$\mathrm{I}(\cdot) \hat{\mathrm{e}}_{\mathrm{it}}$ & $-2.871^{\mathrm{a}}$ & $-3.678^{\mathrm{a}}$ & $-3.874^{\mathrm{a}}$ & $-3.990^{\mathrm{a}}$ & $-4.151^{\mathrm{a}}$ & $-3.360^{\mathrm{a}}$ & $-5.469^{\mathrm{a}}$ & $-3.033^{\mathrm{a}}$ & $-1.773^{\mathrm{b}}$ & $-2.236^{\mathrm{a}}$ & $-3.568^{\mathrm{a}}$ & $-3.390^{\mathrm{a}}$ \\
RMSE & 0.083 & 0.099 & 0.073 & 0.013 & 0.056 & 0.040 & 0.047 & 0.078 & 0.030 & 0.090 & 0.104 & 0.083 \\
Obs. & 5,200 & 2,620 & 5,652 & 1,040 & 524 & 1,256 & 780 & 393 & 942 & 3,380 & 1,703 & 3,756 \\
Banks & 20 & 20 & 18 & 4 & 4 & 4 & 3 & 3 & 3 & 13 & 13 & 12 \\
\hline
\end{tabular}

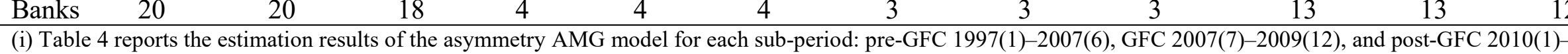
2015(12) for each bank group in successive columns. (ii) The remainders are similar to Table 3. 
Appendix A. Model selection test results

Table A1 Tests for cross-sectional dependence and heterogeneity of the data

\begin{tabular}{|c|c|c|c|c|}
\hline Variable & $\begin{array}{l}\text { Full } \\
(T=706)\end{array}$ & $\begin{array}{l}\text { Pre-GFC } \\
(T=261)\end{array}$ & $\begin{array}{l}\text { GFC } \\
(T=131)\end{array}$ & $\begin{array}{l}\text { Post-GFC } \\
(T=314)\end{array}$ \\
\hline \multicolumn{5}{|c|}{ A. CD statistics (Pesaran 2004) $H_{0}$ : cross-section independence $\mathrm{CD} \sim \mathrm{N}(0,1)$} \\
\hline \multicolumn{5}{|c|}{ Sector } \\
\hline$E R$ & $333.56^{* * *}$ & $205.52^{* * *}$ & $156.30^{* * *}$ & $183.46^{* * *}$ \\
\hline$B B$ & $337.68^{* * *}$ & $222.69^{* * *}$ & $157.47^{* * *}$ & $184.75^{* * *}$ \\
\hline$C R$ & $338.98^{* * *}$ & $222.69^{* * *}$ & $157.34^{* * *}$ & $184.86^{* * *}$ \\
\hline$\triangle E R$ & $129.86^{* * *}$ & $75.50^{* * *}$ & $58.98^{* * *}$ & $74.32^{* * *}$ \\
\hline$\triangle B B$ & $344.97^{* * *}$ & $222.26^{* * *}$ & $154.00^{* * *}$ & $194.06^{* * *}$ \\
\hline$\triangle C R$ & $343.85^{* * *}$ & $222.26^{* * *}$ & $152.94^{* * *}$ & $193.68^{* * *}$ \\
\hline \multicolumn{5}{|l|}{ Major } \\
\hline$E R$ & $64.77^{* * *}$ & $39.49^{* * *}$ & $27.92^{* * *}$ & $43.20^{* * *}$ \\
\hline$B B$ & $65.08^{* * *}$ & $39.57^{* * *}$ & $28.04^{* * *}$ & $43.41^{* * *}$ \\
\hline$C R$ & $65.08^{* * *}$ & $39.57^{* * *}$ & $28.04^{* * *}$ & $43.41^{* * *}$ \\
\hline$\Delta E R$ & $29.50^{* * *}$ & $23.08^{* * *}$ & $12.31^{* * *}$ & $19.15^{* * *}$ \\
\hline$\triangle B B$ & $65.04^{* * *}$ & $39.50^{* * *}$ & $28.04^{* * *}$ & $43.41^{* * *}$ \\
\hline$\triangle C R$ & $65.04^{* * *}$ & $39.50^{* * *}$ & $28.04^{* * *}$ & $43.41^{* * *}$ \\
\hline \multicolumn{5}{|l|}{ Foreign } \\
\hline$E R$ & $45.01^{* * *}$ & $26.93^{* * *}$ & $19.68^{* * *}$ & $30.57^{* * *}$ \\
\hline$B B$ & $46.02^{* * *}$ & $27.98^{* * *}$ & $19.82^{* * *}$ & $30.69^{* * *}$ \\
\hline$C R$ & $46.02^{* * *}$ & $27.98^{* * *}$ & $19.82^{* * *}$ & $30.69^{* * *}$ \\
\hline$\triangle E R$ & $25.86^{* * *}$ & $11.13^{* * *}$ & $12.73^{* * *}$ & $15.81^{* * *}$ \\
\hline$\triangle B B$ & $26.57^{* * *}$ & $27.93^{* * *}$ & $19.82^{* * *}$ & $30.69^{* * *}$ \\
\hline$\triangle C R$ & $26.57^{* * *}$ & $27.93^{* * *}$ & $19.82^{* * *}$ & $30.69^{* * *}$ \\
\hline \multicolumn{5}{|l|}{ Region } \\
\hline$E R$ & $204.80^{* * *}$ & $126.94^{* * *}$ & $100.11^{* * *}$ & $96.96^{* * *}$ \\
\hline$B B$ & $207.09^{* * *}$ & $142.68^{* * *}$ & $100.79^{* * *}$ & $97.78^{* * *}$ \\
\hline$C R$ & $208.32^{* * *}$ & $142.68^{* * *}$ & $100.66^{* * *}$ & $97.78^{* * *}$ \\
\hline$\triangle E R$ & $193.63^{* * *}$ & $45.96^{* * *}$ & $44.14^{* * *}$ & $48.91^{* * *}$ \\
\hline$\triangle B B$ & $195.64^{* * *}$ & $142.41^{* * *}$ & $97.37^{* * *}$ & $119.05^{* * *}$ \\
\hline$\triangle C R$ & $197.01^{* * *}$ & $142.41^{* * *}$ & $96.33^{* * *}$ & $118.64^{* * *}$ \\
\hline \multicolumn{5}{|c|}{$\begin{array}{l}\text { B. Homogeneity Breusch-Pagan LM test results } \\
\text { b1. ER-BB }\end{array}$} \\
\hline Sector & $6753.211^{* * *}$ & $2882.095^{* * *}$ & $3211.747^{* * *}$ & $6798.176^{* * *}$ \\
\hline Major & $555.936^{* * *}$ & $615.779^{* * *}$ & $249.414^{* * *}$ & $318.195^{* * *}$ \\
\hline Foreign & $592.717^{* * *}$ & $250.957^{* * *}$ & $111.066^{* * *}$ & $194.317^{* * *}$ \\
\hline Region & $1407.434^{* * *}$ & $3388.397^{* * *}$ & $1572.373^{* * *}$ & $2923.141^{* * *}$ \\
\hline \multicolumn{5}{|c|}{ b2. ER-CR } \\
\hline Sector & $4294.014^{* * *}$ & $2150.732^{* * *}$ & $2312.629^{* * *}$ & $3728.225^{* * *}$ \\
\hline Major & $373.413^{* * *}$ & $444.324^{* * *}$ & $204.633^{* * *}$ & $132.470^{* * *}$ \\
\hline Foreign & $253.807^{* * *}$ & $343.830^{* * *}$ & $11.745^{* * *}$ & $83.079^{* * * *}$ \\
\hline Region & $773.349^{* * *}$ & $3291.722^{* * *}$ & $719.948^{* * *}$ & $1929.393^{* * *}$ \\
\hline
\end{tabular}

(i) The LM test performs well with small $N$, large $T$ panel data models. (ii) ${ }^{* * *}$ Significance at the $1 \%$ level. (iii) $\Delta$ is the first different operator. 
Table A2 Pesaran (2007) panel unit root test — CIPS

\begin{tabular}{|c|c|c|c|c|c|c|c|c|c|c|c|c|}
\hline & \multicolumn{4}{|c|}{ Mortgage rate $\left(E R_{i t}\right)$} & \multicolumn{8}{|c|}{ The cost-of-funds rates } \\
\hline & \multirow[b]{2}{*}{ Full } & \multirow[b]{2}{*}{ Pre-GFC } & \multirow[b]{2}{*}{ GFC } & \multirow[b]{2}{*}{ Post-GFC } & \multicolumn{4}{|c|}{ Foreign-funds rate $\left(B B_{i t}\right)$} & \multicolumn{4}{|c|}{ Cash rate $\left(C R_{i t}\right)$} \\
\hline & & & & & Full & Pre-GFC & GFC & Post-GFC & Full & Pre-GFC & GFC & Post-GFC \\
\hline \multicolumn{13}{|c|}{ Sector $(N=20)$} \\
\hline $\mathrm{W} / \mathrm{O}$ Trend & $-3.590^{* * * a}$ & $-4.322^{* * * a}$ & $-4.988^{* * * a}$ & $-5.135^{* * * a}$ & $-6.190^{* * * b}$ & $-6.190^{* * * a}$ & $-3.562^{* * * a}$ & $-6.128^{* * * b}$ & $-6.190^{* * * b}$ & $-6.190^{* * * a}$ & $-4.144^{* * * b}$ & $-6.190^{* * * b}$ \\
\hline $\mathrm{W} /$ Trend & $-4.442^{* * * a}$ & $-4.042^{* * * a}$ & $-5.500^{* * * a}$ & $-5.634^{* * * a}$ & $-6.420^{* * * b}$ & $-6.420^{* * * a}$ & $-3.857^{* * * b}$ & $-6.420^{* * * a}$ & $-6.420^{* * * b}$ & $-6.420^{* * * a}$ & $-4.101^{* * * b}$ & $-6.268^{* * * a}$ \\
\hline \multicolumn{13}{|c|}{ Major $(N=4)$} \\
\hline W/O Trend & $-4.183^{* * a}$ & $-4.934^{* * * a}$ & $-6.190^{* * * a}$ & $-6.108^{* * * a}$ & $2.610^{* * * a}$ & $2.610^{* * * a}$ & $2.610^{* * * a}$ & $2.610^{* * * a}$ & $2.610^{* * * a}$ & $2.610^{* * * a}$ & $2.610^{* * * a}$ & $2.610^{* * * a}$ \\
\hline $\mathrm{W} /$ Trend & $-4.464^{* * * a}$ & $-5.511^{* * * a}$ & $-6.385^{* * * a}$ & $-6.391^{* * * a}$ & $1.700^{* * * a}$ & $1.700^{* * * a}$ & $1.700^{* * * a}$ & $1.700^{* * * a}$ & $1.700^{* * * a}$ & $1.700^{* * * a}$ & $1.700^{* * * a}$ & $1.700^{* * * a}$ \\
\hline \multicolumn{13}{|c|}{ Foreign $(N=3)$} \\
\hline W/O Trend & $-4.750^{* * * a}$ & $-3.756^{* * a}$ & $-5.183^{* * * a}$ & $-4.993^{* * * a}$ & $2.610^{* * * a}$ & $2.610^{* * * a}$ & $2.610^{* * * a}$ & $2.610^{* * * a}$ & $2.610^{* * * a}$ & $2.610^{* * * a}$ & $2.610^{* * * a}$ & $2.610^{* * * a}$ \\
\hline W/Trend & $-6.036^{* * * a}$ & $-3.374^{* * a}$ & $-5.413^{* * * a}$ & $-5.542^{* * * a}$ & $1.700^{* * * a}$ & $1.700^{* * * a}$ & $1.700^{* * * a}$ & $1.700^{* * * a}$ & $1.700^{* * * a}$ & $1.700^{* * * a}$ & $1.700^{* * * a}$ & $1.700^{* * * a}$ \\
\hline \multicolumn{13}{|c|}{$\operatorname{Region}(N=13)$} \\
\hline W/O Trend & $-3.547^{* * * a}$ & $-3.058^{* * a}$ & $-5.114^{* * * a}$ & $-4.644^{* * * a}$ & $-6.190^{* * * b}$ & $2.610^{* * * a}$ & $-6.190^{* * * b}$ & $-6.190^{* * * b}$ & $-6.190^{* * * b}$ & $2.610^{* * * a}$ & $-6.190^{* * * b}$ & $-6.190^{* * * b}$ \\
\hline $\mathrm{W} /$ Trend & $-4.366^{* * * a}$ & $-3.798^{* * * a}$ & $-5.538^{* * * a}$ & $-5.371^{* * * a}$ & $-6.420^{* * * b}$ & $1.700^{* * * a}$ & $-6.420^{* * * b}$ & $-6.420^{* * * a}$ & $-6.420^{* * * b}$ & $1.700^{* * * a}$ & $-6.420^{* * * b}$ & $-6.420^{* * * a}$ \\
\hline No. of & 706 & 261 & 131 & 314 & 706 & 261 & 131 & 314 & 706 & 261 & 131 & 314 \\
\hline
\end{tabular}

(i) The null hypothesis of the Pesaran (2007) CIPS test with cross-sectional dependence is $H_{0}$ : (homogeneous non-stationary): bi $=0$ for all $i$ for both constant and constant and trend models. Maximum number of 8 lags is used to determine the optimal lag length and the serial correlation order. Portmanteau (Q) test is set for white noise. (ii) Subscripts ${ }^{a}$ and ${ }^{b}$ denote results obtained at the $1 \%$ level of significance on level and at first difference. (iii) The asterisks ${ }^{*}$, ${ }^{* *}$, and ${ }^{* * *}$ denote the rejection of the null hypothesis at the 10,5 , and $1 \%$ levels, respectively. 
Table A3 Westerlund (2007) Cointegration test

\begin{tabular}{|c|c|c|c|c|c|c|c|c|}
\hline \multirow[t]{2}{*}{ Statistics } & \multicolumn{4}{|l|}{ A. ER-BB. } & \multicolumn{4}{|l|}{ B. ER-CR } \\
\hline & $\begin{array}{c}\text { Full } \\
(T=706)\end{array}$ & $\begin{array}{c}\text { Pre-GFC } \\
(T=261)\end{array}$ & $\begin{array}{c}\mathrm{GFC} \\
(T=131)\end{array}$ & $\begin{array}{c}\text { Post-GFC } \\
(T=314)\end{array}$ & $\begin{array}{c}\text { Full } \\
(T=706)\end{array}$ & $\begin{array}{c}\text { Pre-GFC } \\
(T=261)\end{array}$ & $\begin{array}{c}\mathrm{GFC} \\
(T=131)\end{array}$ & $\begin{array}{c}\text { Post-GFC } \\
(T=314)\end{array}$ \\
\hline Sector & & & & & & & & \\
\hline$G_{t}$ & $-9.653[.000]$ & $-23.183[.000]$ & $-13.645[.000]$ & $14.473[1.000]$ & $-1.292[.148]$ & $-20.409[.000]$ & $-10.244[.000]$ & $25.538[1.000]$ \\
\hline$G_{a}$ & $-16.382[.000]$ & $-38.116[.000]$ & $-19.418[.000]$ & $-6.656[.035]$ & $-2.835[.133]$ & $-63.893[.000]$ & $-26.417[.000]$ & $-3.089[.361]$ \\
\hline$P_{t}$ & $-12.722[.000]$ & $-24.581[.000]$ & $-15.851[.000]$ & $-12.867[.000]$ & $-3.938[.009]$ & $-13.622[.000]$ & $-15.984[.000]$ & $-7.110[.010]$ \\
\hline $\begin{array}{l}P_{a} \\
\text { Major }\end{array}$ & $-20.667[.000]$ & $-38.564[.000]$ & $-25.978[.000]$ & $-11.719[.000]$ & $-4.306[.077]$ & $-27.911[.000]$ & $-41.936[.000]$ & $-10.956[.023]$ \\
\hline$G_{t}$ & $-2.362[.020]$ & $-7.225[.001]$ & $-4.075[.008]$ & $-5.272[.003]$ & $-2.203[.010]$ & $-13.130[.000]$ & $-5.358[.003]$ & $-2.532[.046]$ \\
\hline$G_{a}$ & $-4.028[.005]$ & $-10.153[.001]$ & $-9.066[.001]$ & $-3.900[.029]$ & $-2.371[.043]$ & $-63.089[.000]$ & $-13.218[.003]$ & $-3.976[.061]$ \\
\hline$P_{t}$ & $-5.247[.000]$ & $-8.631[.000]$ & $-4.071[.034]$ & $-5.686[.000]$ & $-3.208[.000]$ & $-9.227[.003]$ & $-7.248[.001]$ & $-3.337[.035]$ \\
\hline $\begin{array}{l}P_{a} \\
\text { Foreign }\end{array}$ & $-8.613[.000]$ & $-16.275[.000]$ & $-10.91[.004]$ & $-5.842[.013]$ & $-3.998[.004]$ & $-40.808[.000]$ & $-17.716[.001]$ & $-5.866[.031]$ \\
\hline$G_{t}$ & $-2.686[.013]$ & $-1.844[.071]$ & $-7.255[.000]$ & $-3.120[.013]$ & $-2.796[.004]$ & $-8.247[.005]$ & $-2.201[.091]$ & $0.625[.828]$ \\
\hline$G_{a}$ & $-3.167[.024]$ & $-3.233[.039]$ & $-7.416[.000]$ & $-1.793[.129]$ & $-3.007[.019]$ & $-49.882[.003]$ & $-4.736[.138]$ & $0.539[.863]$ \\
\hline$P_{t}$ & $-3.443[.004]$ & $-2.123[.218]$ & $-7.233[.000]$ & $-4.712[.004]$ & $-3.291[.001]$ & $-0.806[.486]$ & $-2.538[139]$ & $0.163[.810]$ \\
\hline $\begin{array}{l}P_{a} \\
\text { Region }\end{array}$ & $-4.792[.009]$ & $-3.404[.148]$ & $-8.975[.000]$ & $-3.888[.045]$ & $-4.249[.004]$ & $-2.568[.255]$ & $-8.900[.036]$ & $-0.248[.799]$ \\
\hline$G_{t}$ & $-9.373[.000]$ & $-14.611[.000]$ & $-11.744[.000]$ & $-17.843[.000]$ & $-2.558[.009]$ & $-36.496[.000]$ & $-6.931[.008]$ & $-9.459[.000]$ \\
\hline$G_{a}$ & $-16.698[.000]$ & $-20.817[.000]$ & $-16.354[.000]$ & $-33.684[.000]$ & $-4.676[.006]$ & $-84.419[.000]$ & $-23.767[.000]$ & $-28.511[.000]$ \\
\hline$P_{t}$ & $-10.475[.000]$ & $-6.274[.018]$ & $-12.888[.000]$ & $-13.032[.000]$ & $-3.390[.018]$ & $-1.430[.438]$ & $-9.102[.005]$ & $-6.134[.005]$ \\
\hline$P_{a}$ & $-17.726[.000]$ & $-7.233[.044]$ & $-21.948[.000]$ & $-12.139[.000]$ & $-4.279[.056]$ & $-2.514[.440]$ & $-35.932[.001]$ & $-9.420[.004]$ \\
\hline
\end{tabular}

rate estimations for each bank group in successive columns, while Panel B reports the coefficients of the cash rate. 
Appendix B. Additional tables and figures

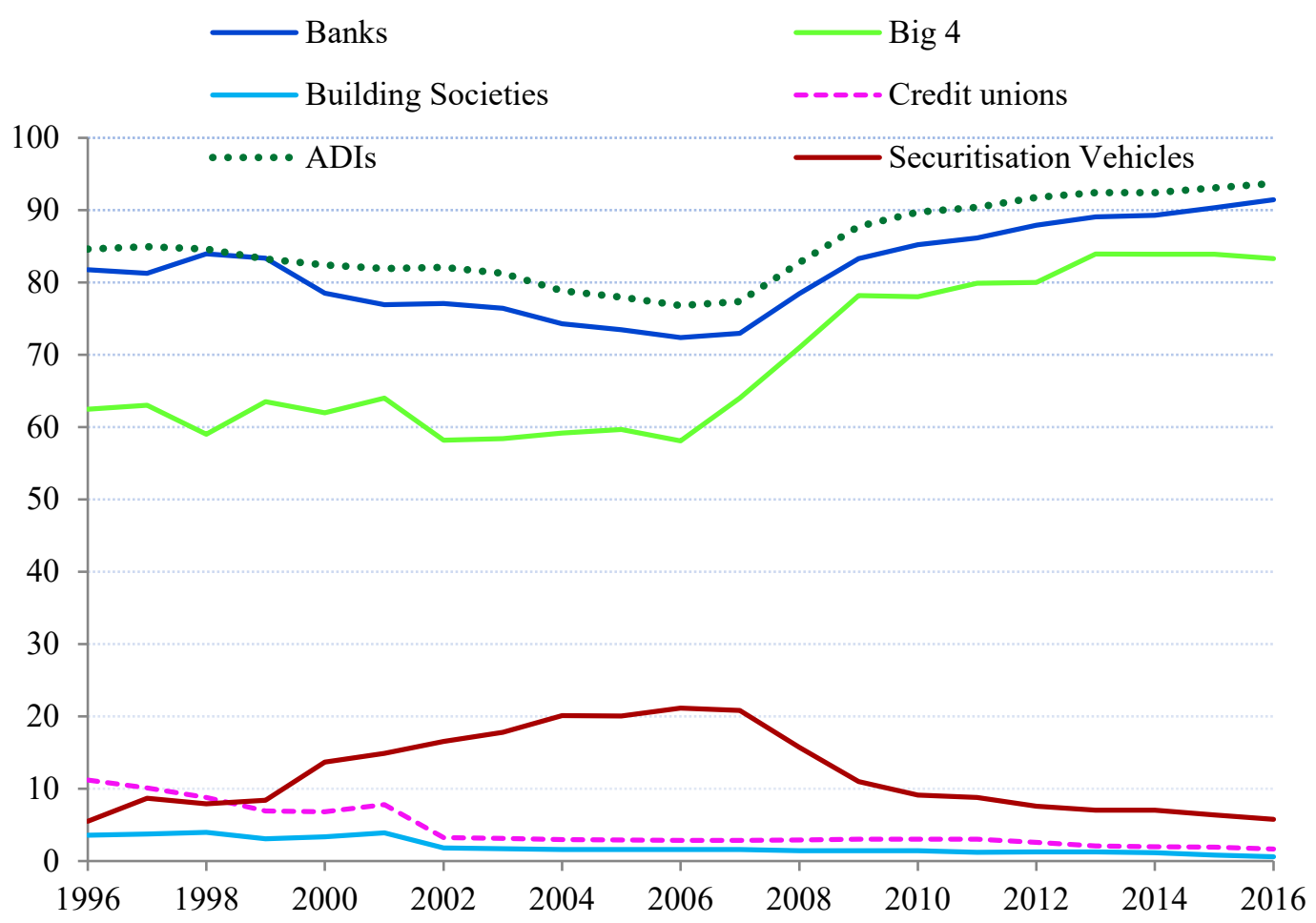

Fig. B1 Mortgages outstanding by lenders in percent. Author's calculation from Sources: APRA 2017 Statistics "Quarterly ADI Performance"; ABS 2017, Table 12 
Table B1 Summary Statistics

\begin{tabular}{|c|c|c|c|c|c|c|c|c|c|}
\hline \multirow[t]{2}{*}{ Variable } & \multicolumn{4}{|c|}{ Mean } & \multicolumn{4}{|c|}{ Std. Dev } & \multirow{2}{*}{$\begin{array}{l}\text { Mean equality } \\
\text { test }\left(\chi^{2}\right)\end{array}$} \\
\hline & Full & $\begin{array}{l}\text { Pre- } \\
\text { GFC }\end{array}$ & GFC & $\begin{array}{l}\text { Post- } \\
\text { GFC }\end{array}$ & Full & $\begin{array}{l}\text { Pre- } \\
\text { GFC }\end{array}$ & GFC & $\begin{array}{l}\text { Post- } \\
\text { GFC }\end{array}$ & \\
\hline \multicolumn{10}{|l|}{ A: Sector } \\
\hline$B B$ & 4.687 & 5.531 & 5.572 & 3.616 & 1.502 & 0.521 & 1.896 & 1.132 & $6.0 \mathrm{e}+03^{* * *}$ \\
\hline$C R$ & 4.450 & 5.362 & 5.289 & 3.454 & 1.432 & 0.489 & 1.750 & 1.079 & $5.8 \mathrm{e}+03^{* * *}$ \\
\hline$E R$ & 7.117 & 7.224 & 7.713 & 6.762 & 0.965 & 0.517 & 1.446 & 0.842 & $4.0 \mathrm{e}+03^{* * *}$ \\
\hline Obs. & 14,120 & 5,220 & 2,620 & 6,280 & 14,120 & 5,220 & 2,620 & 6,280 & \\
\hline \multicolumn{10}{|l|}{ B: Foreign } \\
\hline$B B$ & 4.634 & 5.531 & 5.567 & 3.499 & 1.510 & 0.521 & 1.899 & 1.037 & $914.771^{* * *}$ \\
\hline$C R$ & 4.451 & 5.362 & 5.285 & 3.346 & 1.442 & 0.489 & 1.754 & 0.998 & $885.369^{* * *}$ \\
\hline$E R$ & 7.210 & 7.217 & 7.828 & 6.947 & 0.914 & 0.505 & 1.391 & 0.796 & $587.245^{* * *}$ \\
\hline Obs. & 2,118 & 783 & 393 & 942 & 2,118 & 783 & 393 & 942 & \\
\hline \multicolumn{10}{|l|}{ C: Major } \\
\hline$B B$ & 4.634 & 5.531 & 5.567 & 3.499 & 1.510 & 0.521 & 1.899 & 1.037 & $1.2 \mathrm{e}+03^{* * *}$ \\
\hline$C R$ & 4.451 & 5.362 & 5.285 & 3.346 & 1.442 & 0.489 & 1.754 & 0.997 & $1.2 \mathrm{e}+03^{* * *}$ \\
\hline$E R$ & 7.109 & 7.273 & 7.732 & 6.713 & 0.955 & 0.486 & 1.458 & 0.792 & $925.377^{* * *}$ \\
\hline Obs. & 2,824 & 1,044 & 524 & 1,256 & 2,824 & 1,044 & 524 & 1,256 & \\
\hline \multicolumn{10}{|l|}{ D: Region } \\
\hline$B B$ & 4.715 & 5.531 & 5.574 & 3.679 & 1.497 & 0.521 & 1.895 & 1.175 & $3.9 \mathrm{e}+03^{* * *}$ \\
\hline$C R$ & 4.526 & 5.362 & 5.292 & 3.512 & 1.427 & 0.489 & 1.749 & 1.117 & $3.8 \mathrm{e}+03^{* * *}$ \\
\hline$E R$ & 7.098 & 7.211 & 7.681 & 6.733 & 0.978 & 0.529 & 1.454 & 0.864 & $2.5 \mathrm{e}+03^{* * *}$ \\
\hline Obs. & 9,178 & 3,393 & 1,703 & 4,082 & 9,178 & 3,393 & 1,703 & 4,082 & \\
\hline
\end{tabular}

(i) $B B$ and $C R$ are the international funding cost and cash rate, while $E R$ is the effective mortgage rate variable for each group. (ii) The mean equality, which is the chi-square $\left(\chi^{2}\right)$ distributed, is employed to compare the means for pre-GFC, GFC, and post-GFC periods. (iii) Superscript ${ }^{* * *}$ indicates the $1 \%$ level of the significance, while "Obs" represents the total number of observations. 
Effective Mortgage Interest Rate and Funding Cost Movement
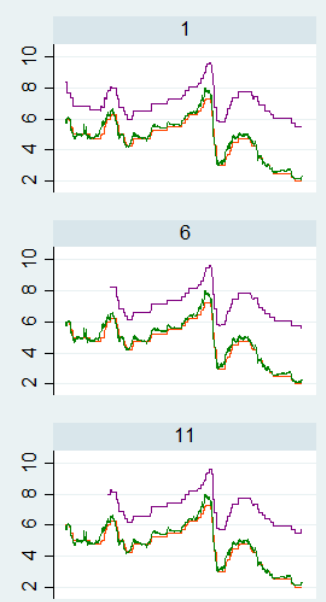

16
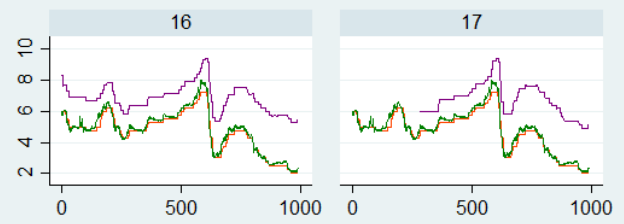
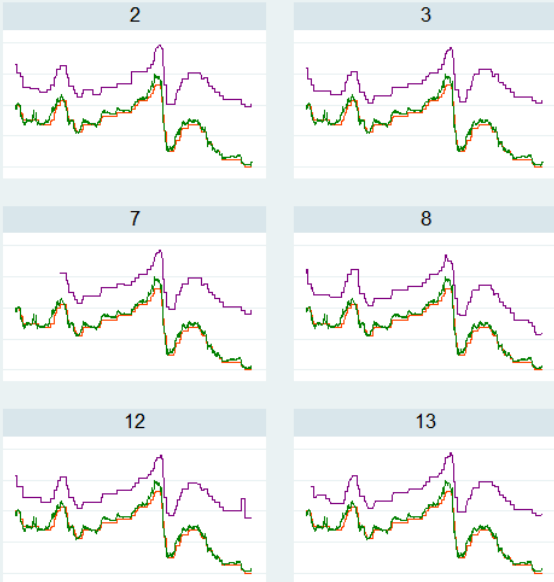

17

ER
8

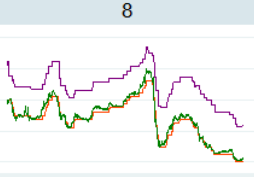

13

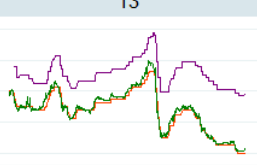

18

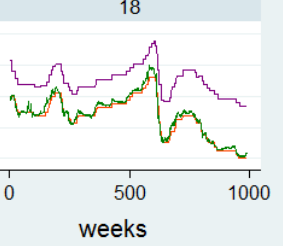

CR
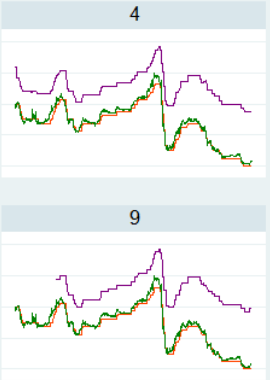

14

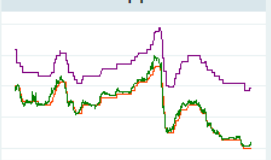

19

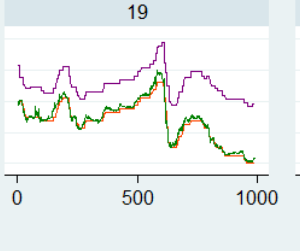

BBSW

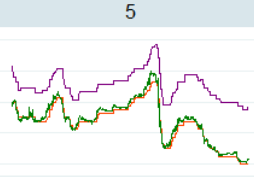

10

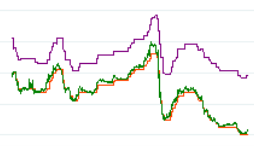

15

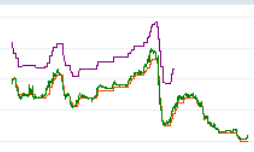

20

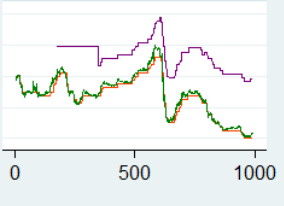

Graphs by ID

Fig. B2 Plots of variables.

Notes: $E R$ denotes "the effective mortgage interest rate" for each bank. $C R$ and $B B S W$ are "the cash rate" and "the 3month bank bill swap rate" as two funding cost proxies, domestically and internationally. 